Florida International University FIU Digital Commons

3-21-2017

\title{
Of Israel's Seed: The Ethnohistory of Church of God and Saints of Christ and African Hebrew Israelites of Jerusalem
}

Remy Chukwukaodinaka Ilona

remy.ilona@gmail.com

DOI: $10.25148 /$ etd.FIDC001762

Follow this and additional works at: https://digitalcommons.fiu.edu/etd

Part of the History Commons

\section{Recommended Citation}

Ilona, Remy Chukwukaodinaka, "Of Israel's Seed: The Ethnohistory of Church of God and Saints of Christ and African Hebrew Israelites of Jerusalem" (2017). FIU Electronic Theses and Dissertations. 3208.

https://digitalcommons.fiu.edu/etd/3208 


\title{
FLORIDA INTERNATIONAL UNIVERSITY \\ Miami, Florida
}

OF ISRAEL'S SEED: THE ETHNO-HISTORY OF CHURCH OF GOD AND SAINTS OF CHRIST AND AFRICAN HEBREW ISRAELITES OF JERUSALEM

\author{
A thesis in partial fulfillment of the \\ requirements for the degree of \\ MASTER OF ARTS \\ in \\ RELIGIOUS STUDIES \\ by \\ Remy llona
}


To: Dean John Stack

Steven J. Green School of International and Public Affairs

This thesis, written by Remy Ilona, and entitled Of Israel's Seed: The Ethnohistory of Church of God and Saints of Christ and African Hebrew Israelites of Jerusalem, having been approved in respect to style and intellectual content, is referred to you for judgment

We have read this thesis and recommend that it be approved.

Erik Larson

Oren Stier

Tudor Parfitt, Major Professor

Date of Defense: March 21, 2017

The thesis of Remy llona is approved.

Dean John Stack Steven J. Green School of International and Public Affairs

Andres G. Gil Vice President for Research and Economic Development and Dean of the University Graduate School

Florida International University, 2017 
(C) Copyright 2017 by Remy llona All Rights reserved. 


\section{DEDICATION}

I dedicate this work to Professor Tudor Parfitt who gave me the opportunity to come to the United States, and engage in the studies that this thesis is one of its products. To my friend Avraham Van Riper who proof-read it, and gave me very vital suggestions. And to my wife Irene, and my children, Daniel, Aliyah, and Sharon who endured my long absence from home. 


\section{ACKNOWLEDGMENTS}

I wish to thank the members of my committee beginning with my major professor, Distinguished Professor Tudor Parfitt, and the other members; Professor Erik Larson and Professor Oren Stier for their support. I really benefitted from their gentle but firm direction and guidance.

I particularly appreciate Professor Parfitt's help in enabling me to identify the methodology and theoretical models, which enabled me to engage with this subject. Professor Parfitt gave me the opportunity to come to Florida International University, to study at what is a vibrant institution. He gave me a

chance to improve myself, and he has stood by me. I will remain forever grateful to him. Distinguished Professor Nathan Katz and Professor Oren Stier worked with Professor Parfitt to enable me to come to FIU. I owe them a debt of gratitude.

I also have sincere and heartfelt appreciation for the others that contributed to getting me where I am today. I should particularly acknowledge the generosity of Mr. Jonathan Symons, Denise and Richard Allen, Cecilia and Herman Storick, Andria Spindel, Avraham Van Riper, Gedaliah Gurfein, Dean Draznin, Ozo Okenwa Ewudo, Emeka Maduewesi, Eric Law, and Chinedu Emelife. In addition I should mention Kulanu, Inc' whose support helped me throughout this period of study.

Finally, I feel indebted to Professor Erik Larson, my head of department, Professor Albert Wuaku, my program director, and all the faculty in my department. If I am a building they are the steel and concrete. 


\author{
ABSTRACT OF THE THESIS \\ OF ISRAEL'S SEED: THE ETHNO-HISTORY OF CHURCH OF GOD AND \\ SAINTS OF CHRIST AND AFRICAN HEBREW ISRAELITES OF JERUSALEM \\ by
}

Remy llona

Florida International University, 2017

Miami, Florida

Professor Tudor Parfitt, Major Professor

The aim of this thesis was to investigate the ethno-history of the Church of God and Saints of Christ and African Hebrew Israelites of Jerusalem. Both religious movements were started by African Americans who passed through slavery. The former started in 1892, and the latter in the 1960s. They claimed an Israelite ancestry, and built their religious movements on what they accepted to be Israelite culture.

I found the basic question to be what made these men claim an Israelite identity. I tried to answer this question by examining the cultural conditions in which the founders of the two movements found themselves when they formed the movements. The methodology that I engaged stresses that culture forges people.

I found that the deracialization that the founders suffered as slaves led them to appropriate an Israelite identity. In turn, this served to restore the dignity of the African Americans. 


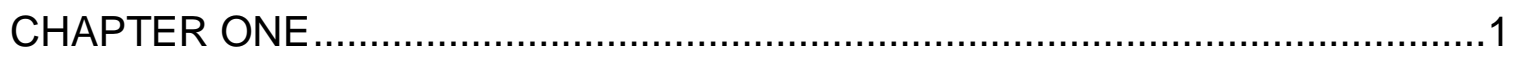

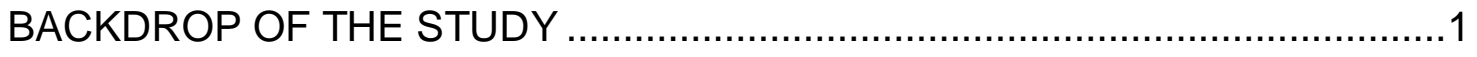

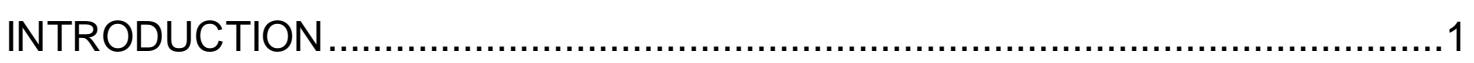

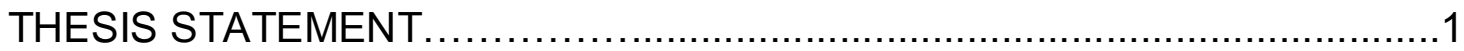

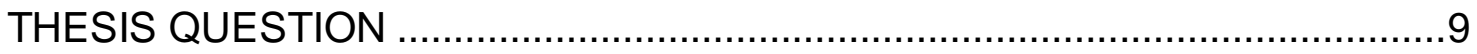

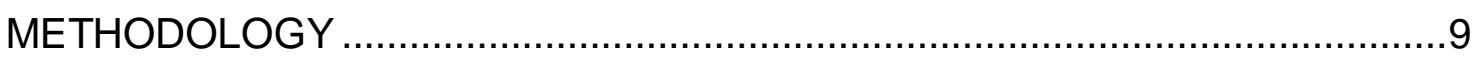

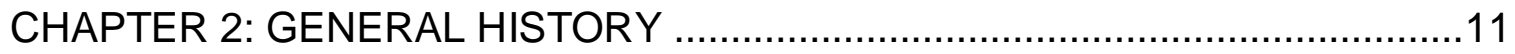

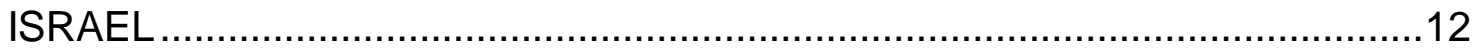

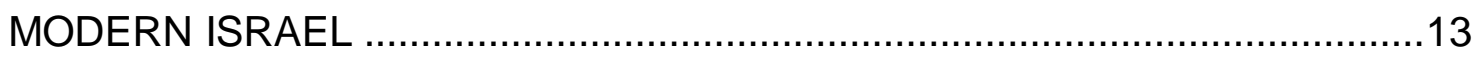

ISRAEL THE HEBREW PATRIARCH .................................................14

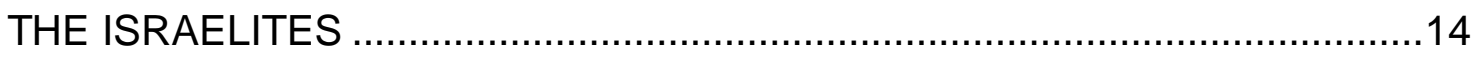

EVOLUTION OF THE ISRAELITE PEOPLE …............................................14

BLACK ISRAELITES AND BLACK JEWS ...............................................17

COGASOC AND AHIJ: PRODUCTS OF THE SLAVE TRADE AND BLACK

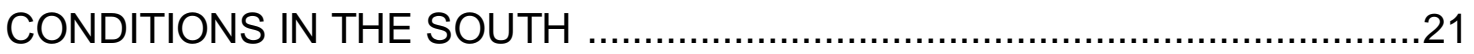

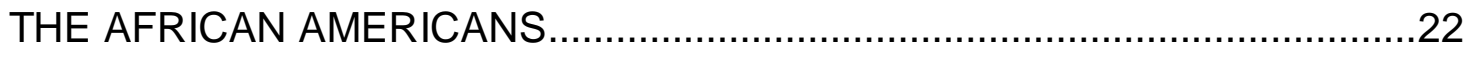

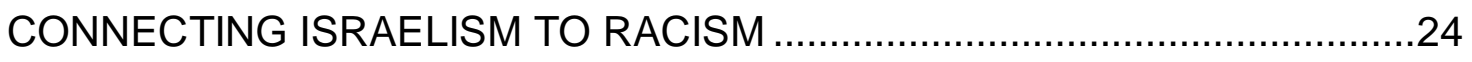

SIMILAR MOVEMENTS: RASTAFARIANS AND MOORS ..........................44

CHAPTER 3: FURTHER DISCUSSIONS AND ANALYSES ….......................47

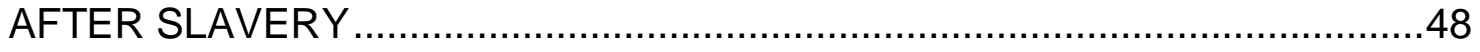

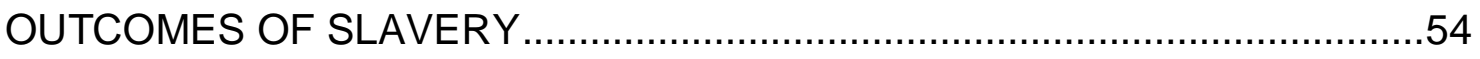

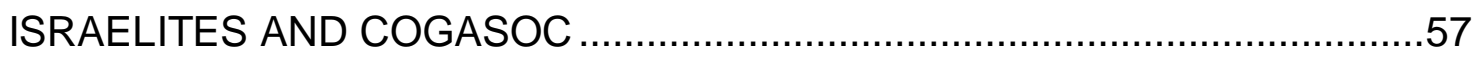

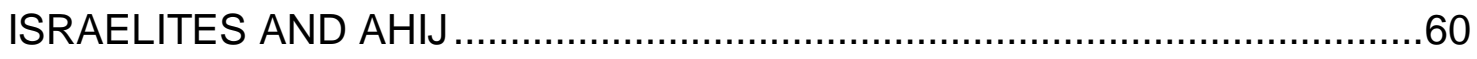

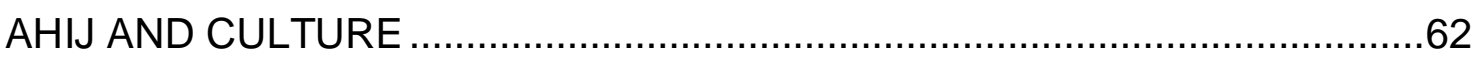

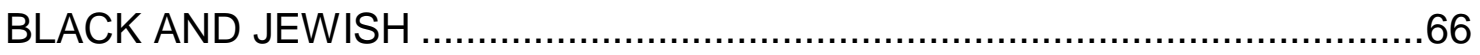




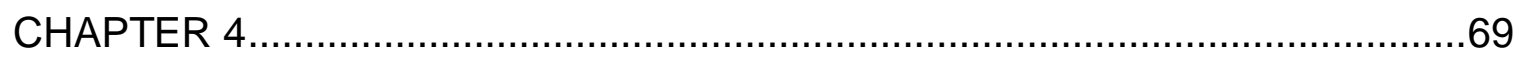

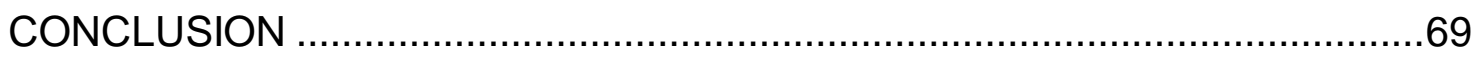

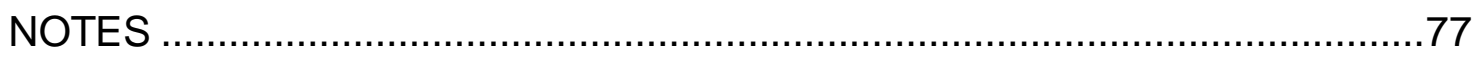

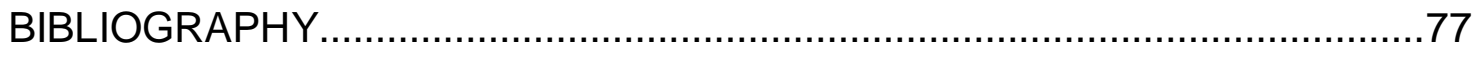




\section{CHAPTER ONE}

\section{BACKDROP OF THE STUDY}

\section{INTRODUCTION}

This thesis is a study of the ethno-history of the Church of God and Saints of Christ (COGASOC) and African Hebrew Israelites of Jerusalem (AHIJ). These broadly speaking are denominations of what may be termed the Black Israelite religion. This religion was formed by African Americans and Caribbeans who claimed to be descendants of the biblical Israelites.

The members of both organizations believe that the cruel and degrading treatment that their ancestors suffered in the trans-Atlantic slave trade was the fulfillment of the curses forewarned in the Book of Deuteronomy, Chapter 28. In that chapter, Moses talked about how the Israelites would be taken into slavery and bondage by their enemies, for disobeying God. They also refer to the degrading treatment that they suffered after the abolishment of slavery as further fulfillment of the Scriptural prophesy.

The Church of God and Saints of Christ and the African Hebrew Israelites of Jerusalem were both founded and developed by individuals attempting to respond to the afore-mentioned mistreatment of African Americans.

\section{THESIS STATEMENT}

The founders of both movements appropriated Israelite identity, and formed the movements in order to substitute a better identity for the shameful identity of slave and ex slave, and the oppressive culture that their oppressors imposed on them. 
To avoid confusion, Black Israelites have also been termed 'Black Jews' by many authors, and we may come across many references to them as such in this study even though they are different from Black adherents of Rabbinic Judaism.

The first movement that we are studying, COGASOC was established by an African American, William Saunders Crowdy, (1847-1908) in Lawrence, Kansas, USA, in 1892. According to Jacob Dorman in Chosen People, "a small clean table came down with the words: "Church of God And Saints of Christ"1 to Crowdy in a vision. This vision was the beginning of COGASOC.

Crowdy was born to parents who were slaves on a farm in Charlotte Hall, Maryland, USA. According to the customs in force in the United States then, as he was born to enslaved parents he was also a slave. The slaves were like other chattel. They could be sold by their owners, so whatever belonged to them belonged to their owners. As we shall see, this fact would influence the identity he forged and the religious choices he would ultimately make. These choices would in time also form the basis of the identity, beliefs and practices of COGASOC.

We do not know much about his early life. But we learned that as a child Crowdy was put to work at the farm and assigned work that was hard for a child. Life was very hard for slaves in the United States so it's understandable that he experienced much hardship as a child. In Church of God And Saints of Christ Elly

1 Jacob Dorman, The Rise of American Black Israelite Religions (New York: Oxford University Press, 2013), 38. 
Wynia wrote that Crowdy "escaped slavery in 1863."2 After escaping he joined the Union Army. And after his discharge he became a cook on the Santa Fe railroad. He started this church while he was still working as a cook. In The Heritage Seekers, Israel J. Gerber wrote that Crowdy as a chef "organized a Black Jewish sect."3

The 'Black Jewish sect', to use Gerber's words, that Crowdy formed, and which we are studying in this thesis has some core beliefs. The one that is most relevant to this study is that African Americans are the authentic descendants of the biblical Israelites. On this Wynia wrote, "The formal theology of the Church is found primarily in the Seven Keys and the Constitution. A summary of the church's constitution is as follows: Believing that the Negro race is descended from the 10 lost tribes of Israel, the prophet (Crowdy) taught that the Ten Commandments and a literal adherence to the teachings of the Bible, including both the Old and the New Testaments are man's positive guides to salvation." ${ }^{4}$ Continuing, Wynia wrote, "The most unusual feature of the faith of the Church of God and Saints of Christ is its synthesis of Jewish and Christian elements." ${ }^{5}$ Wynia found this to be unusual because according to him, "this is apparently the earliest example of so-

${ }^{2}$ Elly Wynia, The Church of God And Saints of Christ (New York: Garland Publishing, Inc.1994), 19.

${ }^{3}$ Gerber, Israel J, The Heritage Seekers (New York: Jonathan David Publishers, 1977), 69.

${ }^{4}$ Elly Wynia, The Church of God And Saints of Christ (New York: Garland Publishing, Inc., 1994), 54.

5 lbid., ix. 
called black Judaism in America." ${ }^{6}$ The presence of Black Jews who professed Judaism had been reported in the Americas many years before Crowdy's time. But those Blacks professed Rabbinic Judaism and not the Black Israelite religion. We will encounter stories about a few of them as we make progress in this study.

It is important to explain very clearly that this study is about the Black Israelites who are frequently misaddressed as Black Jews, and not about Black people who are adherents of Rabbinic Judaism. I will say more about this point very soon. This movement which Crowdy started has spread. It started branches that still exist in many areas of the United States and soon after it began it also became an international movement with branches in other countries.

The other group analyzed in this thesis is the AHIJ. This group has adopted other names over the years such as 'Black Hebrews', and 'Original Hebrew Israelite Nation of Jerusalem. ${ }^{7}$

The African Hebrew Israelites of Jerusalem (AHIJ), which was founded in Chicago by an African American named Ben Carter (1937-2014), in the early 1960s, has very similar beliefs about the origins of African Americans as the older COGASOC.

There are several accounts about what Carter did before he joined the Black Israelite movement. Israel Gerber wrote that he likely was a bus driver. ${ }^{8}$ But it is

\footnotetext{
${ }^{6}$ Ibid., ix.

${ }^{7}$ Israel J Gerber, The Heritage Seekers (New York: Jonathan David Publishers, 1977), 1.

8 lbid., 8.
} 
clear that it was in Chicago that he joined the Black Israelite movement. At the time the movement likely had become institutionalized in the Black community due to the work done by the likes of Prophet Crowdy whose COGASOC we are also studying. Before Ben Ammi's time more than a few other African Americans had taught that the African Americans were the authentic descendants of the ancient Israelites. Considering when Ben Carter was born he very likely witnessed the continuing struggle for dignity and equality that African Americans who had been formally freed from slavery in 1865 had to engage in to attempt to attain civil rights (equal status) with their fellow Americans. After slavery had ended, racial segregation against Blacks was still lawful in some areas in America. Blacks were accordingly looking for solutions. And many were joining associations that could help to solve the problems of the Blacks. John Jackson, who is the Richard Perry University Professor of Communication, Africana Studies, and Anthropology at the University of Pennsylvania, and the author of Thin Description wrote, "Ben Carter was one of those garrulous Chicagoans, someone quite comfortable talking politics and social liberation." 9

In the prevailing condition the Black Israelite movement was one of the movements that Blacks who were looking for solutions could join. According to Jackson, Carter was introduced to the idea that African Americans were descendants of the ancient Israelites by one Elder Buie while both were working in a foundry. After this encounter Carter would begin to frequent Black Israelite

9 John Jackson, Thin Description (Cambridge: Harvard University Press 2013), 41. 
circles. ${ }^{10}$ Inside the Black Israelite community he acquired the name Ben Ammi ben Israel. According to Israel J. Gerber, "Ammi began his study of Judaism around 1960, with a self-styled rabbi who called himself Levi Israel." ${ }^{11}$ Gerber also wrote that Ben Ammi belonged to several Black Israelite communities and eventually assumed the leadership of one. ${ }^{12}$ It is this group that Ben Ammi assumed its leadership that has become the transnational movement called the African Hebrew Israelites of Jerusalem (AHIJ), whose ethno-history will form one of the two main foci of this thesis.

Ben Ammi's group has had a dramatic history. In 1967, very likely in response to the exhortations of Marcus Garvey, Ben Ammi took his group to Liberia in a failed bid to return to the African motherland. Interestingly though his group espoused Israelite ancestry yet it chose Liberia. This likely happened because of one reason. Prior to Ben Ammi's time a man that many people saw as the equivalent of the Jewish Zionist leader Theodore Herzl had risen in the African American community. This man was Marcus Garvey, (1887 - 1940). Before his demise, as a gifted orator and journalist he had inspired many African Americans, among them the leaders of the Black Israelites, the Rastafarian, and the Nation of Islam movements, to think of themselves not as degraded underlings, but as the descendants of a people with great achievements to its name. He fired the imaginations of millions. His 'Back to Africa' movement which promoted the return

\footnotetext{
${ }^{10} J o h n$ Jackson, Thin Description (Cambridge: Harvard University Press 2013),43.

${ }^{11}$ Israel J Gerber, The Heritage Seekers. (New York: Jonathan David Publishers1977), 8.

12 lbid., 8
} 
of the African Diaspora to their ancestral lands very likely as I hinted influenced Ben Ammi's decision to relocate his movement from the United States to Africa. Gerber wrote that African Americans who had become black Jews were among the "New York zealots"13 of Garvey. From the foregoing we can see the likely reasons that made AHIJ to take the step to return to Africa. Even though they claimed an Israelite identity they also viewed themselves as Africans. When his attempt at establishing a colony in West Africa failed Ben Ammi successfully relocated his group to Israel which according to the 'Divine Geography' of the AHIJ is located in North East Africa. The AHIJ believes that Israel is located on the African continent, and that it is identified as a part of West Asia and called part of the Middle East due to Euro-gentile conspiracies. AHIJ's understanding of Geography is called Divine Geography. In this geography Israel which the conventional geography places in Asia is located in Africa. Perhaps this should not be unexpected as the AHIJ believes that the authentic Israelite is an African. Jacob Dorman wrote, "Ben Ammi's attempt to merge Black Jewish identity and religious symbolism with the Return-to- Africa ideology"14 marks out AHIJ as unique. COGASOC merged Jewishness and Blackness (African) but it is not as Africacentered as AHIJ. Though the members of AHIJ had a lot of problems with the Israeli government when they moved to Israel, they are now well settled, and they

\footnotetext{
${ }^{13}$ lbid., 14.

14 Jacob Dorman, The Rise of American Black Israelite Religions (New York: Oxford University Press 2013),57.
} 
look set to continue to thrive, even though their charismatic leader Ben Ammi passed on in 2014 at the age of 74 .

Like the members of the older COGASOC, the members of AHIJ have some unique views of their past, myths of origins, beliefs and practices. I will briefly mention some of the above.

As I have observed, these two groups of Black Israelites were originally African Americans who were slaves or descendants of slaves who claimed that they were the authentic descendants of the biblical Israelites.

Members of both groups believe that their own religion is the authentic form of Judaism. I think that comparing their beliefs and practices with the beliefs and practices of Rabbinic Jews on one point will help us to understand the Black Israelites more. Unlike Rabbinic Jews who use the Hebrew Bible as well as the vast body of Rabbinic texts known as the Oral Law, these two- COGASOC and AHIJ- view the Christian Bible as Scripture, with the Hebrew Scriptures viewed as higher in authority than the New Testament. What do they think of members of the Jewish community who don't have an African background? At best, members of both groups argue that Jews of European and Middle Eastern backgrounds are inauthentic Israelites. At worst they declare them to be impostors. As we engage this study we will find out why they believe or claim that white Jews are not authentic Israelites.

In this thesis I am paying particular attention to the ethno-history of the COGASOC and the AHIJ. Ethno-history is the study of the beliefs, traditions and 
customs of a group or groups conducted by examining historical records, oral traditions, belief systems and mythologies as well as other sources of information.

\section{THESIS QUESTION}

One fundamental question that arises is: why did the Church of God and Saints of Christ and African Hebrew Israelites of Jerusalem decide to appropriate an Israelite identity? Trying to answer this seemingly simple question will untangle a lot of things. For example, we will have to study Israel, albeit briefly from many angles, such as 'Israel' as the Hebrew Patriarch Jacob, as the modern state in the Near East, and at the same time give particular attention to the biblical or ancient Israelites who were the people that Black Israelites claim that they descended from. We will also look at the environment and culture or cultures that facilitated the claim of an Israelite identity, and the flowering of the Black Israelite religious movement. Religions usually come into existence and grow when some stimuli create conditions that call for a religious response.

\section{METHODOLOGY}

I will engage ideas of 'racial theology' developed by Colin Kidd. I will also engage the theoretical model of the concept of 'hybridity' which interrogates and explores the effects of mixture on formation of culture. The acts of de-racialization and reracialization, which we shall see in this study, contributed to the hybridization of the culture of the subjects. 
A considerable amount has been written about the COGASOC and AHIJ. Members of these groups have also contributed to this literature. The studies on the COGASOC and the AHIJ that I am reviewing include Tudor Parfitt's Black Jews In Africa and the Americas, Graenum Berger's Black Jews In America, John Jackson's Thin Description: Ethnography and the African Hebrew Israelites of Jerusalem, Jacob Dorman's Chosen People: The Rise of American Black Israelite Religions, Israel J. Gerber's The Heritage Seekers, Shalomim Halevi's Growing Intellectually, Spiritually and Prophetically In the Hebrew Israelite Culture and Faith, Paul A. Hare's The Hebrew Israelite Community, Howard M. Brotz' The Black Jews of Harlem, Olaudah Equiano's The Interesting Narrative of the Life of Olaudah Equiano, By Shadrock's The Forgotten Israelites, Ben Ammi Ben Israel's God, the Black Man and Truth, Cohane Michael Ben Levi's Israelites And Jews, Shlomo Katz' Negro and Jew, Yvonne Chireau's and Nathaniel Deutsch's Black Zion.

The general studies that I have listed here covered many areas of COGASOC's and AHIJ's history, and the philosophies, outlooks and beliefs of both groups. This study is an enquiry into their ethno-histories. This leads to an investigation into the myths of origin of the founders and members of the movements, the way in which these myths were incorporated into the countertheologies of the two groups, and the cultural developments that motivated them to assume the identity that they have now. 
My research is based on investigation into archival sources, the interviews that other researchers conducted with the leaders and members of both groups, and letters exchanged between them and other researchers.

This study is divided into four chapters. Chapter One, which is the Introduction, has already offered a backdrop to the subject. Chapter Two is mainly a survey of the history that is of importance in studying the ethno-history of the Black Israelites in general, and COGASOC and AHIJ in particular. Here we also systematically inquired into the myths, and beliefs of origin of both groups. Chapter Three analyzes the information in the literature on the COGASOC and AHIJ. In Chapter Four, I tied together the strands of the various arguments of the study.

\section{CHAPTER TWO}

\section{GENERAL HISTORY}

The subjects of the study have claimed that they (African Americans) are the authentic descendants of the Israelites, and that authentic Israelites were black. AHIJ went further to declare that Israel and even adjoining lands are part of Africa. ${ }^{15}$ I believe that because of this, this thesis should have a brief section that attempts to explain the various things that Israel stands for. A basic understanding of these will help us to understand some of the questions that the

\footnotetext{
${ }^{15}$ Paul A Hare, The Hebrew Israelite Community (Oxford: University Press of America, 1998), $42 / 43$.
} 
subject poses, and will also help us to organize the answers that we will come up with.

\section{ISRAEL}

The name or term 'Israel', which is in the title of this study, means many things. The name is the one that God gave to Jacob, the grandson of Abraham who is regarded as one of the Hebrew patriarchs. Israel also stands for Jacob's descendants, who are often called the 12 Tribes of Israel. It also stands for the Hebrews, Israelites, and the Jews. It is also used to refer to the Kingdom of ancient Israel whose first king was Saul as recorded in (1 Samuel 9:19; 1 Samuel 10:1). Israel is also the name of the modern state of Israel. I will begin with a brief discussion about Israel in the category that we will not give much attention to in this study. Israel is a modern state in the Middle East - or in the north east corner of Africa, if we follow and accept the opinion of the African Hebrew Israelites of Jerusalem. Though Israel has perhaps little to do with the ethnohistory of both movements, in the religion of the younger AHIJ which believes in a kind of Zionism, it is important. As the early Zionists saw a return to the Land of Israel by the Jewish people as a critically important objective to the wellbeing of the Jewish people, so did the AHIJ. Zionism which obviously draws its name fromMt. Zion is the national movement of the Jewish people that acted for the reestablishment of a Jewish homeland in the territory defined as the historic Land of Israel. Zionism arose in the 19th century in Central and Eastern Europe as a national revival movement, and as a response to the anti-Semitic dispositions of 
the European states and populations that the Jews lived amongst. At its early stage, Zionist Israelis main focus was to return the oppressed Jews to the historic Land of Israel. Ben Ammi was to later take the same steps that the Zionists took. Viewing the United States as irredeemably hostile to black Americans, he took his followers away from their country to Liberia, and later to Israel. So as we can see AHIJ's 'return' to Israel indicates that the modern state has some measure of importance in the religion of the AHIJ, as it is for most members of the Rabbinic Jewish community.

\section{MODERN ISRAEL}

The Israeli state's rise is generally associated with the visionary activities of Theodore Herzl (1860-1904). Herzl was an Austro- Hungarian Jew who is considered the founder of the movement of political Zionism which led eventually to the formation of the Jewish State. He committed his short life to this effort. He left behind an organized group of followers who saw his vision to fruition.

The exile of the Jews appeared as if it might be an unending reality until the appearance of this Jewish visionary; Herzl, who laid the foundations for the Jewish State. Many people in the world, Jews and Christians, see this state as the re-born Biblical Israel - a resurrected version of the state that the ancient Hebrews established. This Israel is the state to which Ben Ammi Ben Israel led his followers in 1969. 


\section{ISRAEL THE HEBREW PATRIARCH}

Israel also means Jacob, the Hebrew patriarch that the Bible mentions as the son and grandson of the biblical Isaac, and Abraham, respectively. The God of Israel changed Jacob's name to Israel. He was the father of the Twelve Tribes of Israel.

\section{THE ISRAELITES}

Israel also stands for the Israelite people, or the Hebrew people as they were also referred to in very ancient times. The Jews or Israelites or the Hebrews are the descendants of Israel (Jacob). The COGASOC and AHIJ claim that they are the authentic descendants of the ancient Israelites.

\section{EVOLUTION OF THE ISRAELITE PEOPLE}

It is important to understand how the Israelite people that COGASOC and AHIJ maintain that they descended from evolved.

The Israelite people began to evolve into a distinct, separate and unique people according to the Bible when God and their ancestor Abraham entered into a covenant: some of the terms of which include that the people (Abraham's descendants) would always circumcise their sons on the eight day, and live according to certain rules that have been aggregated together, and loosely identified as ethical monotheism. God on His part took upon Himself the job of protecting this people who henceforth also became known as His people, and also God gave them a land that the Bible alternately called the Land of Canaan, the Promised Land and the Land of Israel. The bequest of this land to Abraham 
and his descendants came with a novel condition: that it would only be held or possessed by the Israelites if they kept the commandments of God. This rule or condition has important ramifications, which impact on the subjects of this study as we shall see. For now in order to make the digression less disruptive I will only say that the Black Israelites of COGASOC and AHIJ believe that because they sinned that God threw them out of the Land of Israel and that they ended up in America as slaves, after sojourning in Africa.

The above-mentioned encounter between God and the ancestors of the Israelites gave birth to a culture which is identified with the Israelite people. It is this culture which distinguishes the Israelite people from other peoples. Before Abraham encountered God he was not distinct from his neighbors and peers. Abraham and his offspring were essentially biologically not different from their neighbors, but culturally and in religion they began to become distinct after their encounter with God, because what God dictated and they accepted to live by was a culture. The grundnorm of the culture is found in the Torah. What the religious culture that emerged from the encounter and deal with God did is akin to what Collin Kidd observed that culture does in The Forging of Races: Race and Scripture in the Protestant Atlantic World, 1600-2000. After looking critically at race and culture he observed ".....races are products of culture rather than biology." 16

\footnotetext{
${ }^{16}$ Colin Kidd, The Forging of Races (Cambridge: Cambridge University Press 2006), ix
} 
The conclusion that Kidd reached about the role of culture in forging of people is in conformity with my point that it is the religion and culture of Israel that forged the people of Israel into a distinct and unique people. The following illustration will help to make my point more clear. There is a Jewish community in Africa called the Abayudaya Jews. The Abayudaya Jews of Uganda who were fourteen different ethnic groups with different languages and cultures converted to Rabbinic Judaism in 1992. They are a very good example of a group conversion to a culture. Presently the Abayudaya Jews are one 'tribe'-Jews, or Black Jews, as much Jewish as their Western co-religionists in Israel and the United States. In their Western style skull-caps which they wear when they are observing their religious rituals they could be mistaken for Israelis of Ashkenazi and Sephardic extractions if not for their darker skin color. The same could be said of the San Nicandro Jews who originally came from Italy. Both groups of recent converts have been successfully forged into Jews by their adhesion to Jewish culture. The Abayudaya whose conversion was in the 1990s have been recognized by the Jewish Agency. This was widely reported in the Jewish press. The Jerusalem Post of April 12, 2016 carried the news. ${ }^{17}$

In this study our objective is to investigate the ethno-history of COGASOC and AHIJ. To obtain the right answer we are looking at why the founding fathers of COGASOC and the AHIJ claimed that African Americans are descendants of the ancient Israelites. This claim and the developments that have set these

\footnotetext{
17 Jerusalem Post, Ugandan Jews get official recognition from Jewish Agency, http://www.jpost.com/Diaspora/Ugandan-Jews-get-official-recognition-from-Jewish-Agency451008-02/18/17.
} 
African Americans apart came about during, and after their experience as slaves in the United States.

From being just African Americans they have become Black Israelites. They are presently a distinct group with beliefs, traditions and practices unique to themselves. The culture which they developed as a response to slave conditions has also enabled these descendants of slaves to do other things like development of their own theology which some view as a counter-theology. Some think that it is their adoption of an Israelite identity, and invention of their own Judaism that have enabled the members of these two communities: COGASOC and AHIJ to maintain persistent action in the face of such adverse conditions as are faced by Black people in their communities. To investigate the ethno-history of COGASOC and AHIJ we have to look seriously into the culture of the slave owning world that forged the members of each of the two movements into distinct groups that are different from even similar peoples.

\section{BLACK ISRAELITES AND BLACK JEWS}

For various reasons that have important ramifications for this study, I think that it is necessary to make clear at this stage whom this study is about, and whom it is not about. This study of COGASOC and AHIJ is about the African Americans who claim that they are the authentic descendants of the biblical Israelites. It is not about other Jews of African extraction that are also called Black Jews. These persons are members of the religion addressed as Rabbinic Judaism. Many times these persons are mistaken for the Black Israelites, because the numerous 
African-Americans that have converted to the religion of Rabbinic Judaism also retain the identity 'black' even as they have the identity 'Jew.'

It is also not about other Blacks like the Abayudaya (Children of Judah Jews of Uganda), the Bnei Yeshuroun (Children of Yeshuroun Jews of Cameroun), and the groups of Madagascans who recently converted to the religion of Rabbinic Judaism. Rather as I pointed out it is about the group or groups that identify themselves, and are identified as the Black Israelites. I am stressing this because COGASOC and AHIJ have been identified in numerous studies as Black Jewish movements but the members generally don't see themselves as Jews, but as Israelites or Hebrews. Also unlike the Black Israelites the Ugandan Abayudaya, the Bnei Yeshuroun, and the groups of Madagascans who converted to the religion of Rabbinic Judaism in 2016, did not claim descent from the ancient Israelites, they converted, and they refer to themselves as Jews. Also, unlike the above-listed Ugandans, Camerounians and Madagascans who as converts to Rabbinic Judaism are accepted as co-religionists by Rabbinic Jews, the Black Israelites who do not convert to Rabbinic Judaism, are also not recognized as co-religionists by adherents of Rabbinic Judaism. Black Israelites of course do not recognize adherents of Judaism as authentic Israelites, and also they view Rabbinic Judaism as not wholly authentic.

I am making this point because many people mistakenly think or believe that these groups (Black Rabbinic Jews and Black Israelites) are the same or are more connected than they actually are, especially when the Black Rabbinic Jews 
(adherents of Rabbinic Judaism) are Americans. Why this occurs is interesting.

Israel and the Jewish identity have been constructed in the public consciousness and imagination as 'white' and 'European' so effectively that all non 'white' peoples who identify with Israel by way of religion or ancestral claims and assertions are aggregated together, and viewed as the same-'the other'-who at best must be converts. The group or groups meant as non 'white' peoples here are the Ethiopian Jews, and the Cochin Jews from Cochin in India, and peoples of sub-Saharan African background. Perhaps this is because many peoples in this category have skin tones that are most different from the skin tones of the most dominant 'Jewish' groups: the Ashkenazim and the Sephardim. The following excerpt which recounts a personal experience of the late Rabbi Hailu Paris, a prominent Black Israelite rabbi both illustrates and highlights this point: "...........He loved to tell the story of his life-changing journey. When the ship pulled into the port of Bremen, Germany, late in 1935, Nazis boarded looking for Jews. His mother was carrying a Torah that was being returned to their synagogue in Harlem. It was wrapped in a blanket, which also covered her young son's shoulders. "They rounded up everyone sitting nearby," he told me, "but they ignored us, because they never thought black people could be Jews." He added with his ever-present chuckle: "As you know, there are many white Jews today who still feel that way."18

\footnotetext{
${ }^{18}$ Len Lyons, Losing A Gentle Lion of Judah, Tablet, http://www.tabletmag.com/scroll/186964/losing-a-gentle-lion-of-judah -2/4/2017.
} 
The reification of Israel and Judaism into 'white' and European has been so effective that Israel Gerber made the following claim as a matter of fact:

"Even if Palestine were joined to Africa as they (Black Israelites) claim, it is situated in that part of the continent where the people are regarded as European, not African. The Patriarchs were not blacks nor were the Israelites who dwelled in Egypt. Racially they are classified as European or Caucasoid, while American Negroes are mostly of African origin." ${ }^{19}$ From what we can see, Gerber presents the view of Judaism and Israel as both a racialized religion and entity. This reinforces retention of the identity 'black' for the non 'white' person that converts to Judaism. Interestingly, as we would see in this study the racialization of Judaism would be one of the reasons why the African Americans who became founders and members of COGASOC and AHIJ would make the choice to become Israelites. As we would see in the following sections of this study there are more than a few factors that could suggest or indicate to the African Americans who had been deracialized and whose identities had been replaced with the various identities: slave and ex-slave, that they were descendants of the ancient Israelites. And when both the need and the opportunities came for the black Americans to replace these hated identities with a more respectable identity which would give meaning to their lives, they appropriated the identity 'Israelite' because not only did it give meaning to their lives, but it was also tied to

\footnotetext{
${ }^{19}$ Israel J Gerber, The Heritage Seekers (New York: Jonathan David Publishers1977), 67.
} 
race, and was accordingly a suitable identity to be used to replace the hated 'racial' identities that the world of slavery had allotted to them as their racial identities. In succeeding sections we will see how the Black Americans were able to explain why they: 'black people', are Israelites too.

In the following section we will study briefly the origins of the African Americans. We will skirt the borders of the experiences, and traumas that this group passed through, and that made individuals like Crowdy and Ben Ammi to make the choices that they made. Why did they form this belief that they are the authentic Israelites? Why did they think that Jews of non African (Black) extraction are inauthentic, and why did they declare them so? In the following sections we will attempt to answer the questions.

\section{COGASOC AND AHIJ: PRODUCTS OF THE SLAVE TRADE AND BLACK}

\section{CONDITIONS IN THE SOUTH}

At the beginning of this chapter we explored Israel from many positions so that the reader who is not very familiar with Israelite history and culture will know something about both the people that the African Americans claim that they descended from, and the land that they assert that their ancestors were thrown out of. We also dealt briefly with the modern Israel that AHIJ returned to because of its belief that it is its ancestral homeland.

I also think that a very brief account of the beginnings of the African Americans, and their unique suffering in the United States will be enlightening, 
especially to the reader who is not very familiar with the history of the African Americans. This is because they influenced the choices that the people that became the Black Israelites of COGASOC and AHIJ made. Prophet Crowdy as we have noted above was born into slavery, and he escaped from it to meet the deeply discriminatory world that the southern part of the USA was after the end of the Slave Trade. Hereafter I will recount a very brief narrative about the beginnings of the African Americans, what they experienced after they landed as slaves, and what they faced after they secured their freedom.

\section{THE AFRICAN AMERICANS}

The African Americans are mainly the descendants of slaves-people who were brought from their African homelands by force to work in the New World. For five hundred years many European nations sent fleets of ships to mainly West Africa, and to a lesser extent Central and South West Africa, to smuggle captive Africans of very diverse ethnic backgrounds to the Americas and the Caribbean, to work as slaves in plantations. From members of the Yoruba, Fulani, Wollof, Mende, Temne, Ibibio, Efik, ljaw, Ashanti, Hausa, Ibo, Ewe, and the numerous other ethnicities that were captured and enslaved, they were turned into 'blacks', 'negroes', and then 'slaves.' 'The Slaves' became their ethnicity, their race, and their identity. One pernicious myth that their oppressors called a theory was that 'blacks' were inferior and were thus fit to be slaves. The Black was, in the understanding of the slave owning society in the Americas good only for slavery as he purportedly was a descendant of Ham, who was cursed by his father Noah 
for mocking his nakedness. ${ }^{20}$ "Slaveholding, as it developed in the United States, differed from servitude practiced in other countries. Americans used slavery to degrade and dehumanize blacks, stripping them of every vestige of human dignity, until the term 'slave' and the slave system incorporated unprecedented racial doctrines." 21

From the foregoing we can see that in the culture of the United States during the antebellum period that slavery had been constructed into a racial category, and the color of the victims became the chief marker or identifier of the 'slave race.' Even after slavery had ended the rights of the African Americans were severely curtailed, and they were for a very long period mistreated, segregated, and were not allowed to have their fair share of the economic, social, and political opportunities in the United States. Until the enactment of the Civil Rights Act in 1964, they were not allowed to use the same amenities that the whites used. The Voting Rights Act of 1965 gave them the right to vote.

After slavery had ended, the mistreatment of the people was mainly based on their color which in the view of the society was the color of the slave race. As we saw, the slave owning society viewed the slave who was African as a member of a racial category. Being slave meant being a member of the slave race, and since the slaves were dark-skinned Africans the color of the Africans became the color of slaves. The society could not accept that members of this

\footnotetext{
${ }^{20}$ David Goldenberg, The Curse of Ham: Race and Slavery in Early Judaism, Christianity, and Islam. (Oxford \&Princeton: Princeton University Press 2005),56.

${ }^{21}$ Israel J Gerber, The Heritage Seekers (New York: Jonathan David Publishers1977), 177.
} 
race (the slave race) should be their equals, so the suffering of the Black Americans continued. This culture which held that Blacks was inferior contributed to the choices that Crowdy and Ben Ammi made. As we have noted above, culture and not biology forges people.

\section{CONNECTING ISRAELISM TO RACISM}

Britain was the colonial master of the United States. British culture was one of the basic cultures in the country, and during the antebellum period, British ideas and influences still came to the United States. Interestingly the racism, racist attitudes and doctrines which were developed and deployed by some British racists whose ideas moved to the USA was to some extent hinged on formulations of Israelite exceptionalism. Anglo-Israelism which was prominent and influential in $18^{\text {th }}$ and $19^{\text {th }}$ centuries Britain and the United States attempted to formulate and propagate a myth that the British themselves were of Israelite stock. The exponents also stressed that this was responsible for Britain's success, and that this accordingly made the British racially superior to other stocks. Of course in the United States, the oppressed and enslaved Blacks were among the assumed inferior racial stocks. The most visible in fact because of their color. One of the Anglo-Israelites, Edward Hines was to say, “...we have literally fulfilled Israel's mission by pushing the aborigines of our colonies to the ends of what was once their own country, as we require more room, so do we push, drive them into the corners. These we have done to the Caffres, the Maoris, the Bushmen of Australia.....All our aborigines are positively dying out, 
gradually but surely, before us." 22 As Hines saw it, it was England's affinity to Israel that made it so successful in empire-building, mistreatment of, and suppression of inferior peoples. This sentiment was so widespread in Britain and the British colonies that much scholarship was devoted to it. Reporting on the seriousness that discussions of Anglo-Saxon exceptionalism with its mythical linkages to the ancient Israelites attracted in England, Joseph. J. Williams wrote: "The discussion now became general, (after some notable Englishmen had tried to rebut the circulating tale) and the literature on the subject extensive. Space will permit only a few random comments in passing. Thus one writer finds in this theory, facetiously we suspect, the explanation of how despite many miscalculations, the ambitions of Britain are usually crowned with success. "Why should so small a country as Britain" he asks, "possess such great influence over the world as she does, and be successful in all her wars, notwithstanding that she continually makes the most palpable blunders? We have many faults, socially, nationally, and individually, to confess and bemoan; yet, for all that, it will be admitted that we are 'a great nation.' What is the secret of Britain's greatness? If it is proved that the British are Israelites, the whole History of England will be understood with a right point of view; and that is, that God's dealings with her, being Israel, show forth that He is true, faithful, and 'Covenant

22 Tudor Parfitt, Black Jews In Africa and the Americas (London: Harvard University Press 2013), 69. 
keeping'?: this is the true secret of England's greatness and not any inherent goodness that rests in her or in her people."23

Ideas of this nature which linked racial superiority to Israelite superiority and exceptionalism circulated freely in England and in the Americas, and eventually English racists were to take them into the Christianity that was the main and primary religion in the United States before, during and after the antebellum period. Anglo-Israelite Charles Fox Parham who was born in 1873, and who is credited to have popularized the Pentecostal brand of Christianity has been accused of having had racist views, and has been alleged to have preached against intermarriage because of "woeful intermarriage of races" 24 between supposedly the human race, and some "dark pre-Adamic race."25 In Parham's case he singled out the dark-skinned peoples for opprobrium. The racism discussed here was alive and well in the world in which these captive men and women including Crowdy who founded the COGASOC struggled to be free, to escape, and generally failed, so they toiled and died in the plantations for centuries. We must think that preachments like the one articulated by Parham might have reached the ears of some African Americans who were also members of the same American society. And that such preaching which extolled

\footnotetext{
${ }^{23}$ Joseph Williams, Hebrewisms of West Africa-From The Nile to the Niger With The Jews (New York: Biblo and Tanen1928),118,119.

${ }^{24}$ Tudor Parfitt, Black Jews In Africa and the Americas (London: Harvard University Press, 2013), 71.

25 lbid., 71.
} 
Israelitishness might have registered in the minds of some. From the forgoing again we could see that as these unfortunate captives toiled, they were also exposed to information that discussed them as a group that was racially inferior, and that linked the superiority of their oppressors who were the whites to Israel. We have to assume that the Blacks heard their oppressors saying that the Blacks were inferior. And that they were also familiar with writings which extolled their oppressors and denigrated them. In Black Jews in Africa And The Americas Tudor Parfitt discussed ex slave William Charles Pennington, and his book, $A$ Text book of The Origin and History etc of the Colored People. Pennington had not only written a good book by 1841, but in Parfitt's words, he "very ably, systematically, and ironically refuted white claims to innate racial superiority."26

As the slaves very likely heard all these which expressed and implied Israelite exceptionalism, and made being Israelite a very desirable objective, they also heard things that could make them to think that they were Israelites. In 1789 Olaudah Equiano published his The Interesting Narratives of the Life of Olaudah Equiano, which by the standards of his time was a best-seller. This autobiographical work by Equiano made quite a stir in the slave owning world. Both the author and the book merit a brief discussion.

Olaudah Equiano from what we learned from his biography was born in 1745 in Essaka, (Iseke) Eboe country. This would be in what is now lgboland,

${ }^{26}$ Tudor Parfitt, Black Jews In Africa and the Americas (London: Harvard University Press, 2013), 80. 
Nigeria. From Equiano's recollections many years after, both he and the sister were kidnapped as adolescents and sold to slave traders headed to the West Indies. While in slavery he spent some time in the state of Virginia, in the USA. He also worked for a long time in slave ships and with the British Navy. One of the captains that he served gave him the name Gustavus Vassa, which became his more popular name though he retained Olaudah Equiano his Eboe name under which he published his autobiography. As a slave to sea captains Equiano traveled extensively, visiting England, Holland, Scotland, Gibraltar, Nova Scotia, the Caribbean, Pennsylvania, Georgia, and South Carolina. It is likely that he must have discussed his origins with the slaves that he met during his travels. He eventually saved enough money to buy his freedom, and settled in England in 1767, where he educated himself and worked for Dr. Charles Irving. Equiano published his autobiography, The Interesting Narrative of the Life of Olaudah Equiano or Gustavus Vassa the African, in 1789 as a two-volume work. It had one American and eight British editions during his lifetime. Following the publication of his Interesting Narrative........, Equiano traveled throughout Great Britain as an abolitionist and author. He was one of the most important leaders in the abolitionist movement. This must have increased his clout, and enhanced the reach of his book, and speeches. He married Susanna Cullen, interestingly an Englishwoman of not common birth in 1792. The couple had two daughters. Equiano died young in London in 1797.

In the book, Equiano, offered that even though the religion of the Eboes had in his opinion decayed that it was still unmistakably similar to Judaism. He 
discussed several Eboe customs and compared them to Jewish customs. This made his book exceptional and weighty, because unlike many other writers whose books only mentioned that Jews were in Africa, Equiano actually discussed the customs of the Eboe and likened them to Jewish customs. The book made serious impact in the whole society.

Some scholars have argued that Equiano was a pseudonym, and that the writer could have simply written what he heard about what was the land of the Eboes (Igbo-land). Many others have argued that the writer must have been very familiar with the locales and customs that he described so succinctly. This study is not the apt one in which to investigate, and determine which of the two positions is more valid. In a way those that argue that Equiano might not have been in Africa, and that he might have written what he heard make the case that there was a fairly established and solid knowledge that there were people that were like Jews in the West African region from which the slaves were taken.

The Blacks in captivity, like Crowdy likely heard about Equiano, and read his book. And very likely they also read other books that mentioned or discussed the presence of Jews in Africa.

The scholarly work A Textbook of the Origin and History etc of the Colored People (1841) by Charles Pennington (1807-1870) that we just discussed was one such book. The casual way that the author mentioned that there were black Jews from Judaea on the coast of Africa suggests that Pennington and many other Blacks felt that the presence of Jews in West Africa 
was not unusual. ${ }^{27}$ From this we get the impression that the Blacks in the United States were aware of the information that there were Jews in West Africa. Pennington's odyssey as a run-away slave, and career as a clergyman and an abolitionist gave him a pulpit. We can expect that he likely talked and preached about what he wrote. Both Equiano and Pennington were Blacks. Their audiences must have included fellow Blacks. George Thomas Basden (18731944) was a Welshman who lived in the area that became Nigeria for a long time. He was educated at the CMS College, Islington, and Durham University, United Kingdom. During his sojourn in West Africa he lived and worked as an Anglican clergyman among the people that were the subjects of Equiano's report: the Igbo. He was close enough to the people that he learned their language and wrote two outstanding books about their culture that contributed to the discourse about the presence of people who were like Jews in West Africa. He devoted large sections of his two books: The Niger Ibos (1938), and Among The Ibos of Nigeria (1921), to discussions and comparisons of the lgbo people, and the Israelites.

In all likelihood Basden's studies which have remained influential to date must have reached many in the United States where the former slaves may have read them, or learned about discussions generated by them.

\footnotetext{
${ }^{27}$ Tudor Parfitt, Black Jews In Africa and the Americas, (London: Harvard University Press, 2013),
} 
In his book, Chosen People, Jacob Dorman wrote: “... In 1650, a Dutch rabbi published a book proposing that scattered fragments of the Lost Tribes of Israel, dispersed during the ancient Babylonian captivity, could be found among contemporary peoples of Asia, the Middle East, Africa, and America." ${ }^{28}$

What would be the effect of a book like Equiano's and some of these other books on an enslaved people that had been reading the Bible? A people that had been reading about the subjugation and enslavement of the Hebrews in Egypt, their redemption from slavery, and had probably been seeing themselves because of their plight as very similar to those ancient Hebrews? In an insightful article Rabbi Sholomo Ben Levy submits that the African slaves saw themselves as those Israelites. His words were: "Many African Americans who practice Judaism today maintain that they have always had a close affinity with the Hebrews of the Old Testament. This is true whether or not they recall particular rites that remind them of the Jewish traditions they now follow. Scholars such as Albert Raboteau have described in books such as Slave Religion that the biblical struggles of the Hebrew people--particularly their slavery and exodus from Egypt-bore a strong similarity to the conditions of African slaves and was therefore of special importance to them. This close identification with the biblical Hebrews is clearly seen in the lyrics of gospel songs such as "Go Down Moses" and remains a favorite theme in the sermons of black clergy today."29

\footnotetext{
28 Jacob Dorman, The Rise of American Black Israelite Religions (New York: Oxford University Press, 2013), 69.

${ }^{29}$ Sholomo Levy, The Black Jewish or Hebrew Israelite Community, Jewish Virtual Library, http://www.jewishvirtuallibrary.org/jsource/Judaism/blackjews.html -9/12/2016
} 
One can reasonably think that some who could have drawn near to seeing themselves as the facsimiles of the biblical Hebrews would see the evidence in Olaudah Equiano's Interesting Narratives.... as proof that they were not just like the Jews, but that they were the descendants of the Israelites who were the progenitors of the Jews. Meanwhile the information that there were Blacks that were Jews kept on infiltrating America.

The story of Ethiopia and its Jews, perhaps inevitably reached the Americas, and in time it was to influence the African Americans and play a role in their adhesion to Judaism and appropriation of an Israelite identity. The presence of Jews who were called Falashas, but are presently called the Ethiopian Jews in Ethiopia has long been known about in the Western world including America. Jacques Faithlovich (1881-1955) who fought for their inclusion in world Jewry visited the United States several times presumably to raise funds. The visits were well reported in the Jewish and non Jewish press. ${ }^{30}$ We have to think that it is likely that the slaves also like everybody else followed the news about the Jews in Ethiopia, in their case, maybe even more avidly, because the news was about Africa, the homeland that they were torn away from. With time, even though Ethiopia was not one of the prime areas from which the slaves were taken and brought to the Americas, it became the place that some would point to as their Jewish homeland. This should be expected because the slaves, whose

\footnotetext{
30 Tudor Parfitt, Black Jews In Africa and the Americas (London: Harvard University Press, 2013), 85 .
} 
knowledge of their real ethnic identities had been seriously abridged by the deracialization that they suffered when they landed in the Americas, may likely have thought that Ethiopia was just a part of a culturally monolithic Africa. In America during the antebellum period, the slaves were just 'slaves' or 'negroes', who were brought from Africa, to both the slave owners and the slaves themselves. That Africa was one huge continent with many ethnic groups with vastly different cultures was not something that anyone was aware of. Educating themselves about Africa was not one of the objectives of the slave owners. We can assume as well that educating the enslaved Africans about the native populations of Africa, and their cultures would not have been important to the slave owners. From the foregoing we can see some of the possible reasons that impelled some of the African Americans to identify their Ethiopian Israelite roots in West Africa. Prominent African American rabbi Wentworth Arthur Matthew who by government records was born in Nevis and St. Kitts identified his Falasha place of ancestry as Lagos (West Africa). ${ }^{31}$ So there would be little doubt that studies such as Equiano's and Basden's could have led many, including some of the enslaved Africans to conclude that there were Jews who were indigenous to West Africa. African American, Rabbi Arnold Ford, identified his Israelite ancestry both from the Yoruba who are in the area that became Nigeria, and the Mende ethnic group of Sierra Leone. What books that discuss possible or likely Jewish presence in West Africa could very likely have suggested to the African

\footnotetext{
${ }^{31}$ Jacob Dorman, The Rise of American Black Israelite Religions (New York: Oxford University Press, 2013), 156.
} 
Americans could also have been accomplished by both stories about the Falashas, and by their possible presence in the New World. Some of them might actually have visited the United States. ${ }^{32}$

If Jews had been 'discovered' in West Africa, and in East Africa (Ethiopia), I think that a group that had been torn away from Africa, deracialized, foisted with a hateful identity that has reasons to think that it might have connections to Israel would see the 'discoveries' as proof that it is a group that descended from the Israelites.

More attention needs to be given to the reasons that made Ethiopia particularly alluring to the African Americans who in time became the Black Israelites. The Queen of Sheba that was mentioned in the Book of (1 Kings 10: 1-14) is widely believed to have reigned in Ethiopia, though some positions locate her and her kingdom where Yemen is today. Ethiopians, Africans and African Americans strongly believe that she was an Ethiopian queen. We shall discuss the Ethiopian tradition about her. According to the Ethiopian lore which is preserved in the Kebra Negast ${ }^{33}$, which contains the important foundational myths of Ethiopia, the Queen of Sheba married King Solomon, and they consummated the marriage after which she returned to her country and had a child that was fathered by the Israelite king. The child lived with the mother, until he reached adolescence when he went to Jerusalem to see his father, who after receiving his son, sent him

\footnotetext{
${ }^{32}$ Israel J Gerber, The Heritage Seekers (New York: Jonathan David Publishers1977), 15.

${ }^{33}$ Hebrewisms of West Africa-From The Nile to the Niger With The Jews (N.Y: Biblo and Tanen,1928), 162.
} 
back to Ethiopia with Israelite priests, important personalities and a copy of the Ark of the Covenant. This lore that the Queen of Sheba was a ruler of Ethiopia who visited King Solomon in Jerusalem connects Israel and Ethiopia in remote antiquity, even before we learned about the Ethiopian Eunuch of Acts 8: 27 who visited Jerusalem and was baptized by Philip (Acts 8:26-40).

We have to assume that Crowdy and many other slaves were familiar with stories like these. Black Israelite Rabbi Arnold Josiah Ford actually visited Ethiopia, and settled there to practice Judaism. ${ }^{34}$ The knowledge about Ethiopia and its 'Jewishness' must have been quite strong in the African American community for a rabbi to have made the move of relocating to Addis Ababa.

Ethiopia was to be refreshed in the public consciousness again when Menelik became emperor, and after he had successfully repulsed Italian colonialist ambitions. The Italians who had long desired to have their own African empire were handed a significant defeat by Ethiopian forces at the famous battle of Adwa in 1896. With this defeat Italy conceded to Ethiopian independence. This event had nothing to do with Judaism in Ethiopia but it kept Ethiopia in public consciousness, and limelight.

The Jewish story of Bata Kindai Amgoza ibn Lobagola (1877-1947) is very interesting, insightful and at the same time revealing about how forgeries can help to create realities; in this case of Jews in Africa. This fellow was an American who was born in Baltimore, in the United States. His real name was

\footnotetext{
${ }^{34}$ Israel J Gerber, The Heritage Seekers (New York: Jonathan David Publishers1977), 15.
} 
Joseph Howard Lee. He developed an interesting career making up stories about his Jewish past in a corner of Yoruba territory (Ondo Forests), which is in what became Nigeria, and these stories he told to audiences that were enthralled about exotic places. This impostor was not discovered to be a fraud during his life-time even though he had a chequered career. He was arrested several times due to homosexual activities, mainly involving underage individuals. In spite of these setbacks Lobagola as he called himself maintained a long and colorful career posing as an African 'savage', during which he delivered lectures at many institutions and conducted public debates, about his 'Jewish' origins. Major publisher Alfred Knopf even published his story, Lobagola; an African Savage's Own Story and sponsored speaking tours for him. Lobagola was to eventually die in prison. His story very likely reached the ears of African Americans. ${ }^{35}$ It is possible that Lobagola's story was one of the sources that implanted the Yorubas in the Israelites in Africa category. Rabbi Wentworth Arthur Matthews, of the 'Commandment Keepers of the Living God' who was a prominent Black Israelite rabbi was to claim that he came of Falasha stock from Lagos. Lagos is the chief town of the Yoruba people; who also inhabit the Ondo forests that Lobagola made up stories about as his native land.

Another work that was like Lobagola's career, and book in some ways was Hebrewisms of West Africa-From the Nile to the Niger with the Jews ${ }^{36}$ which was

\footnotetext{
35 Tudor Parfitt, Black Jews In Africa and the Americas (London: Harvard University Press. 2013),95.

${ }^{36}$ Hebrewisms of West Africa-From The Nile to the Niger With The Jews (N.Y: Biblo and Tanen,1928).
} 
written by British monk Joseph J. Williams S.J. This best-selling book, which was also very influential, came close to suggesting that almost all the ethnic groups in Africa were Jews. The book, published in 1928 was also very likely read by African Americans.

The very prolific and imaginative English novelist Sir Henry Rider Haggard (1856 - 1925) also published several successful novels, some of which, like She suggested that there were Jews in Africa. Another successful novel of his, King Solomon's Mines, while not saying directly that there were Jews in Africa, certainly could have set the imagination of many afire because of its title which suggests that the mines of the great Israelite king Solomon, was in Africa.

Like the other books that discussed the issue of Jews in Africa, not only African Americans would have read King Solomon's Mines. American whites were likely to have also read it, and accordingly would have contributed to the discourse both by word of mouth and in writing.

In addition to books that discussed the presence of Jews in Africa, the African Americans could have also heard about Black Jews in America, or even seen them.

Graenum Berger wrote about the sighting of a Black Jew in the United States in the $17^{\text {th }}$ century:

"In the course of time an occasional Jew did settle in Boston and was apparently unmolested. One such resident named Sollomon had the bad judgment to travel towards New Hampshire on a Sunday in 1668. This was 
no mean offense in a day when men were sentenced to a month in jail if they missed church on Sunday. Sollomon's journey did not pass unnoticed, and he was brought before the court in Ipswich. The outcome of the case may never be known, but one phrase in the brief court record challenges the attention of the passing reader. Sollomon is described as a 'Malata Jue' (Mulatto Jew). The first Jew living in New England, as far we know, was of Negro descent! One can only conjecture who this man was. Perhaps he had been born of a slave mother and a Jewish father who had set him free."37

Writing about a black Jewish woman when slavery was still ongoing Graenum Berger remarked, "It is not known whether Lucy Marks, a member of the Congregation Mikveh Israel, was the descendant of one of the Black Jews who came up from the lands or was a former slave of Rachel Marks. She was a devout observer of the precepts of Judaism, and following the traditional custom, she joined the ladies of Mikveh Israel in the separate seating assigned to women by practice and code." 38

While we could not find out the numbers of the Black Jews that lived in the United States, and that the African Americans heard about in the antebellum period, we can speculate that the presence of Black Jews in any number at all in the United States of the antebellum period was bound to be news, both to the

\footnotetext{
${ }^{37}$ Graenum Berger, Black Jews In America (N.Y: C.S.R.FJ.P., 1978), 11.

38 Ibid., 11.
} 
general public, and to the African Americans, basically for different reasons. To the white general public it was going to be news because even though there were speculations about exotic Jews in exotic places, an exotic (Black) one in real life must have seemed strange. In the United States in the antebellum period, the Jews were viewed as a race, just as the Blacks/slaves were also viewed as a race. And both were not seen as one race. The news of Black Jews would impact on the African Americans in a different way. It would strengthen their conviction that they too were Jews.

In an article which is entitled Locating Afro-American Judaism: A Critique of White Nomativity, and which is about the place of the New World in the formation of African American Judaism Black Israelite professor at Savannah University, Georgia, USA, Walter Isaac called for:

“..... both a new historiography of Black Jews based on the colonial interaction between European Jews and enslaved Africans and a social science methodology grounded in this historical reality." 39

Andre Keys another Black Israelite professor while discussing Walter Isaac's position observed: "Isaac in challenging the general consensus that Jewish slaveholding in the Western hemisphere had a negligible impact on the emergence of Black Judaism, proposed a historiography that treats the entire

\footnotetext{
${ }^{39}$ Walter Isaac, Locating Afro-American Judaism: A Critique of White Normativity http://onlinelibrary.wiley.com/doi/10.1002/9780470996645.ch30/summary /12/4/2016.

37 Andre Keys, Toward a Typology of Black Hebrew Thought and Practice, (https://www.academia.edu/8807806/Toward_a_Typology_of_Black_Hebrew_Thought_and_Prac tice)/ 12/5/2016
} 
Atlantic world as a cultural hearth for the creation of New World Black Judaism. The kind of Afro-Jewish studies that Isaac proposes is more holistic than white rabbinic normative Black Jewish studies, with its focus on identity." 40

As we can see, there were many sources indirectly telling, suggesting, and hinting to the African Americans that they too could be Jews, so it is not hard to see how the move to appropriation of the Israelite identity could have happened when the conditions for it to happen existed. It doesn't stretch the imagination that some would see the evidence in a book like Olaudah Equiano's Interesting Narratives.... as proof that they were not just like the Jews, but that they were the Jews. Remember, the slave owning society deracinated the slaves. It turned them into one ethnicity: the slave race, and bequeathed one identity; the slave identity to them. And we cannot imagine that the Blacks were happy with this identity even when they could do very little about it. Also we cannot imagine that the African Americans all came to accept that their racial identity had always been 'slave.' From the reaction of the African Americans when they got some power to do something about their circumstance we know that they did not accept that they were in slavery because they belonged to the slave race, but because they were Israelites who sinned against God, Who punished them by allowing their enemies to enslave them.

Colin Kidd in Forging of Races argues that culture and not biology forges people. ${ }^{41}$ As we are beginning to see in this study the African Americans were

\footnotetext{
${ }^{41}$ Colin Kidd, The Forging of Races (Cambridge: Cambridge University Press 2006), ix.
} 
gradually forged into one people by the 'culture' that ruled their lives-from when they became captives, to when they entered the plantations and other places of servitude as bondmen. The culture deracialized them. From natives of very different African ethnic groups they were turned into members of the slave race or ethnic group. And according to the culture, the proof of their origins as slaves was their blackness (skin-color). This was to play no small part in the formulation by the African Americans that only Blacks were Jews, and that non Blacks were either converts or impostors. We can see how the Blacks could have come to see things this way. The culture in which they were forged had reified blackness into the color of slavery, and the slaves and ex slaves had no choice than to accept that the slave peoples including the Hebrew slaves in Egypt whom they had reasons to see as their ancestors were black. Remember in their own case they had already been turned into one people: the slave people. From the slave people they became the Israelite race. If they had not been deracialized and converted to one people, it is doubtful that they would have declared that the African Americans that were actually descendants of numerous different ethnic groups were just descendants of the ancient Israelites.

Again we can only improve this study by mentioning the role that religion played in the effectiveness of the deracination and reracination. During a class on Vodou in Haiti with Professor Albert Wuaku of the Religious Studies Department of Florida International University, Miami, I wanted to know why the Africans that were enslaved in Haiti retained much knowledge of their history and religion, and those in the Americas apparently didn't. Some of the answers that 
my question elicited included the following: the Catholicism that the Africans that were enslaved in Haiti had to face was more accommodating and tolerant of the traditions of the African slaves. But the Protestant faith intolerantly fought anything that seemed religious or cultural that the slaves practiced. The effect of this was that the slaves in the United States of America were left without culture. And without culture there would be no identity except the identity 'slave' and 'exslave after the abolishment. The foregoing does not mean that the slaves gave up their identities without a struggle. As humans naturally struggle to preserve their treasures among which identity is prime, the slaves must have struggled to preserve their identities, but that was a battle against overwhelming odds. The society that was built on slave labor was far stronger than the slaves. It didn't allow slaves from one ethnic group to remain together. Also, it exposed the slaves to the intolerant Protestantism that fought whatever they retained as cultural memories. Dispersed and Christianized, retention of culture and identity was more difficult. Humans need identity. The need for identity is perhaps as important as the need for oxygen. So we can speculate that even after the slaves had been effectively deracinated, and reracinated that they still sought to have 'their identity' back. In the United States of America during the era of slavery there were still other identities beside the 'slave identity' that had been foisted on the African; that were in captivity. There was 'white', which the slaves could not claim for obvious reasons. The color of the African Americans was quite more different from the white color which was the color associated with the color of the slave owning class, which of course the African Americans did not belong to, as 
they were descendants of slaves who belonged to another race-the slave race. Also, after the end of slavery there was the 'one drop rule' which was brought in to keep the ex-slaves in their place-if I may say their race. This was used to ensure that the races were kept apart. The one-drop rule is a social and legal principle of racial classification that was used in the United States to declare that any individual with even one ancestor of sub-Saharan-African ancestry ("one drop" of black blood) is a black person. So black which was connected to the slave identity they had to remain unless they could devise a way to adopt another identity.

From what we can see, one identity among the various identities that were available, and that was open to the slaves was an Israelite identity, because the experiences of the Israelite slaves in Egypt resemble theirs, which could have suggested to them that the Hebrew slaves were the same people as themselves. Also, from the foregoing the slaves and ex-slaves who had been deracinated and reracinated saw evidence that seemed compelling to them that there were actually Israelites in Africa which was where they came from. In addition the Israelite identity was far better than the slave identity. There was a need, and adoption of an Israelite identity met that need. Crowdy who was the founder of COGASOC, and Ben Ammi who founded AHIJ both adopted an Israelite identity because of the above-stated reasons. 


\section{SIMILAR MOVEMENTS: RASTAFARIANS AND MOORS}

There are similarities between the reasons behind the African American adoption of an Israelite identity, and African American adoption of a Moorish identity, and the Rastafarian's claim of Israelite origins. The African American claim of Moorish identity and in Jamaica the Rastafarians claim that they were the Israelites arose because of the need to discard an identity that was degrading. These groups also passed through the degradations of the Trans Atlantic Slave Trade.

Rastafarianism is a religious movement that was started by oppressed Blacks in Jamaica in the first half of the $20^{\text {th }}$ century. Like the founding fathers of the COGASOC and AHIJ these Jamaicans were Africans who were torn from their homelands, dehumanized in plantation slavery and who were also deracialized. By the $20^{\text {th }}$ century they had became 'free', but they were still haunted by slavery. The culture that they were freed into was one that perpetuated their status as ex-slaves which was as un-dignifying as that of slave. They were stuck in the same groove that the African Americans who became the Black Israelites were stuck in. Doing what the African Americans like Prophet Crowdy did with COGASOC, the Jamaican Blacks fought back! They came back with the Rastafari movement! They claimed that they were descendants of Israelites and invented a religious tradition that enabled them to cope with the society that gave them almost no chance or advantages. ${ }^{42}$

\footnotetext{
42 Barry Chevannes, Rastafari-Roots and Ideology (New York: Syracuse University Press, 1994), 72.
} 
Another parallel movement is the Moorish Movement. There are several organizations in this movement. We will discuss the Moorish Science Temple of America. This is an American national and religious organization that was founded by Timothy Drew (1886-1929), who christened himself Noble Drew Ali after he had become Moorish. Still looking for alternatives to the hated 'slave' and 'ex-slave' identity, he developed the belief that African Americans were descended from the Moors of North West Africa and accordingly were Moorish by nationality and Islamic by faith. Ali assembled aspects of major traditions to create a message of personal transformation through education, racial pride and spiritual uplift-ment. His doctrine was also intended to provide African Americans with a sense of identity in the world and to promote civic involvement. By becoming Moors, the followers of the Moorish movement were no longer slaves and ex-slaves by race. ${ }^{43}$

Like the Black Israelites' appropriation of an identity that they considered better, the primary belief of the Moorish Science Temple that African Americans are of Moorish ancestry, specifically from the Moroccan Empire is also an adoption of an identity. Ali taught that the Moroccan entity extended southwards to the areas from which the captive African Americans were brought. Here he was in similar company with AHIJ which its Divine Geography incorporates Israel as a part of Africa.

${ }^{43}$ https://www.britannica.com/topic/Moorish-Science-Temple-of-America-02/16/17 
As we can see these movements were started by persons that passed through experiences that were as similar and as harrowing as those that the African Americans that became the founders of COGASOC and AHIJ passed through. Members of both of the afore-mentioned movements were also deracialized and reracialized. From Africans from distinct African ethnic groups they were turned into members of the slave and ex-slave race. When they had the chance, they claimed 'racial' identities that to them were better than the racial identities of slave and ex-slave that their oppressors foisted on them. In the case of the Rastafari they also adopted the Israelite identity, but they reinterpreted Israel as an African location, highlighted Ethiopia as the fountainhead of Zion in their theology, and made Haile Selassie their hero, their messiah and their god. In the case of the Moorish, they adopted an imagined and invented Moorish ancestry. Both proceeded to start new religions as the Black Israelites of COGASOC and AHIJ did. And in all cases the new religions served as tools of empowerment which added meaning to the lives of the African Americans and Caribbeans.

All the afore-mentioned identities were deemed to be better than the slave and ex slave identities. In the case of the founders of COGASOC and AHIJ as we can see the cultural conditions that they endured made them to see themselves as a people that were like the ancient Israelites, or that were descendants of the Israelites. The same conditions primed them to appropriate the Israelite identity which was far better than the identity that the world of slavery bequeathed to them. After the adoption of the identity the next step that they took 
was the formation of their movements which they claim that their beliefs and practices are representative of true Judaism. Indeed culture forges people! The culture of the slave owning society of the United States forged the African Americans that started the COGASOC and AHIJ.

\section{CHAPTER 3}

\section{FURTHER DISCUSSIONS AND ANALYSES}

In the previous section we examined the general history of the Israelites, the land of Israel, and looked at the beginnings of the parent stock of COGASOC and AHIJ, the African Americans. What we saw was the world of slavery. It was a world of violence, indignity, deracination, and humiliation. It also produced a unique culture that ultimately turned COGASOC and AHIJ, or led them to become Israelites. As we can see, while this world told the slaves that they were just blacks and slaves, this world also created grounds for them to see themselves as more than just blacks and slaves. The grounds existed for them to see themselves as Israelites who were enslaved because they sinned, and who would be redeemed at the right time. From what we saw in the previous section, the deracialization of the African Americans, and reracialization which converted their status as slaves to a racial category affirmed by the color of their skins introduced a need for reracialization again. This need led to adoption of an Israelite identity for the founders of COGASOC and AHIJ. With this need partially met the founders of the movements in rejection of the culture that oppressed 
them, went back to what they accepted to be their true culture as Black Israelites. To Crowdy and Ben Ammi, the formations of COGASOC and AHIJ, where reclamations of the original faith of the African Americans.

In this section we shall engage in more intensive analysis of why they made the choice. And go beyond to investigate why Crowdy and Ben Ammi responded to oppression by starting Church of God and Saints of Christ and African Hebrew Israelites of Jerusalem. Brief analysis of the culture of each of the two movements will be helpful as we study their ethno-history.

\section{AFTER SLAVERY}

Eventually through legislation, slavery was abolished in the United States. There was resistance to the abolishment, and a war was fought to enforce the abolition. That a war had to be fought to stop slavery demonstrates how deeply the United States was invested in slavery, and the culture of slavery, which among other things produced what we know as racism in the United States. The Merriam Webster dictionary defines racism as "a belief that race is the primary determinant of human traits and capacities and that racial differences produce an inherent superiority of a particular race." 44

The culture in post-abolition America was still oppressively racist. The freed slaves had been freed on paper, but they were not actually free. As we will see soon the unforgiving society nurtured on the culture of racism was not ready to accept the Black man as anything but a slave. Why should it? In the imagination

${ }^{44}$ Merriam-Webster, (Springfield: Merriam-Webster, Inc., 2016) 
of the members of the society the Black person belonged to the slave race, and had to remain in his category. The conditions of the Blacks remained very difficult. Their political and economic rights as a free people was not guaranteed. Cruel laws were put in place to keep them down as a group that was deemed not to be equal to other members of society. The descendant of slaves could also not claim equality with their ex-masters. What I just described was the prevailing condition in the United States that the African Americans regained their freedom in. The Black Code of Mississipi tells the story of the conditions that the African Americans faced after 'freedom' succinctly. According to the Code, "Under the pressure of federal bayonets, urged on by the misdirected sympathies of the world in behalf of the enslaved African, the people of Mississippi have abolished the institution of slavery......We must now meet the question as it is, and not as we would like to have it....The negro is free, whether we like it or not....To be free, however, does not make him a citizen, or entitle him to social or political equality with the white man." 45

Crowdy, the founder of COGASOC was born during slavery, and he tried to free himself from it by escaping. However, it was the above-described world that was still very difficult for the ex slaves that he met after slavery had been abolished. And this culture that was used to run that world still viewed the 'free' African Americans as people that were not equal to the free members of society due to their past as members of the slave race.

${ }^{45}$ Elly Wynia, The Church of God And Saints of Christ (New York: Garland Publishing, Inc., 1994), 3. 
Crowdy was to speak about the inhuman conditions imposed on the Blacks after he started to preach. In his words, "had the[y] seen those things which I spoke about above they would not have had time to formulate a plan of Jim-crow separation nor for barbecuing men and women of the colored races." 46

Conditions such as the one described above by Crowdy impelled Crowdy and Ben Ammi to make the choices that they did. The conditions of their people needed the kind of responses that they came up with. For us to get another clear picture of the conditions faced by the Blacks, let me quote author Charles Price, "Deracination stresses the implications of uprooting, extirpation, and cultural alienation for identity (e.g., the issues that Fanon and Cesaire raised). Enslavement, life as chattel, Black codes, Jim Crow laws, denial of formal education, the promotion of Eurocentric perspectives and persistent poverty are only a few of the obvious ways in which deracination had shaped the contours of Blackness in the Americas." 47

On this same theme Gerber wrote, "...Black servants became chattel, and the principle of presumption arose among the colonists concerning them. Slavery was decreed hereditary, and blackness became the basis for belonging in the slave category." 48

\footnotetext{
${ }^{46}$ Elly Wynia, The Church of God And Saints of Christ (New York: Garland Publishing, Inc., 1994), 51.

43 Charles Price, Becoming Rasta (New York: University Press, 2009),117.

44 Israel J, Gerber, The Heritage Seekers (New York: Jonathan David Publishers19770),191.
} 
African American writer Rudolf Windsor writing in his From Babylon To Timbuktu, adds "The word identity refers to a people's nationality, culture, history, and language; a people gets its nationality and language from the nation to which they belong. Germans are from Germany, Chinese are from China, Egyptians from Egypt, Mexicans from Mexico, and black Americans from where? Of all the nationalities in America, black Americans are the only ethnic group that is not called by its true national name." 49

From the foregoing we can see that the conditions called for, or existed for the Blacks to do something about their condition. The adoption of the Israelite identity as a replacement in place of the obnoxious identities of 'slave' and ex slave was one of the steps that they took. Inside or embedded in this move was the creation of a parallel culture completely different from the one that the cruel society that oppressed the African Americans lived by. This parallel culture which came with the reclaimed Israelite identity also produced the COGASOC and AHIJ, which to Crowdy and Ben Ammi respectively their theologies and doctrines reflected the true religion of the Israelites. There were several outcomes of this move. The following discussion will highlight some of them.

When Crowdy declared that the African Americans were descendants of the Israelites, he reclaimed the dignified identity that had been lost. Great meaning came into the unique suffering that the African Americans and their ancestors passed through. The suffering no longer seemed meaningless. They

\footnotetext{
${ }^{49}$ Rudolf Windsor, From Babylon To Timbuktu (Chicago: Lushena Books. 1969),
} 74,75 . 
suffered because they disobeyed God. They were His chastened children. This was, and is quite comforting!

Also by this exceptional move, the African American reclaimed 'his history and culture' which the world of slavery took away from him. It is safe to speculate that the slave traders and owners could not have had detailed knowledge of which slave was Ibo, which was Asante, which was Yoruba, and so on and so forth, at the point of entry into the United States so it can't be seriously considered that they would retain this knowledge. Accordingly we can assume that as soon as the slaves entered the plantations, the process of becoming just 'slaves' quickly began. Accordingly with time, much personal and group history was lost. So was culture. All that would have remained would be what was left, i.e., what they became after they had been reracinated into the slave race.

We can conjecture that by Crowdy's time that many of the African Americans in slavery likely did not know that as Africa was composed of different ethnic groups with fundamentally different cultures, histories and identities, that they too had different origins. I believe that it is safe to speculate that whatever the memory could dredge up would not have been acute enough to afford the victims knowledge of the actual situation in the continent. They would have tended to see Africa as they saw themselves: as one people with one culture. This would help to explain several things. For example this may throw light on why the founding fathers of the COGASOC and AHIJ observed that the African Americans as a whole were the descendants of the ancient Israelites. They did not just say that they specifically and their followers; members of COGASOC and 
AHIJ, were Israelites, but that the African Americans were Israelites. From what we have seen so far the deracination and reracination that this group suffered very likely affected how they perceived Africa. Having become one people I believe that they also thought that all Africans in the homeland were one people too. This I could say because it was not one people, but many peoples of African descent that constituted the African Americans yet the African Americans, Crowdy and Ben Ammi in this case claimed that they (African Americans) were the descendants of one people: the Israelites. This perception of Africa would in time become moderated as the African Americans began to know more about Africa. Much later, when Ben Ammi wrote God the Black Man and Truth we see that he must have realized that Africans were as diverse as Europeans and this reflects in one of his responses. He wrote, "In both language and customs, the retention of certain Hebrewisms is evidence of the connection between the two groups. It only supports the contention that African Americans are descended from not only the Ashantis, the Fulani, Ewe, Yoruba and Bantu nations but the ancient Hebrews as well." 50

Crowdy chose Israelite, declared the Negroes in the United States descendants of Israel, and set in motion the great process of healing his people. The appropriation of the Israelite identity and the formation of COGASOC restored the lost culture. As the Blacks became the Israelites they left the Christianity that was the religion of their oppressors and returned to a Judaism that they believed

\footnotetext{
${ }^{50}$ Ben Ammi Ben Israel, God, the Black Man and Truth (Washington: Communications Press, 2004), 12.
} 
and thought that it was not only their original faith, but the authentic Judaism. Their own brand of Judaism!

We know that by Ben Ammi's time that much the same situation obtained, and that this must have made AHIJ to take off with the exact foundational myth of origin that COGASOC took off with.

\section{OUTCOMES OF SLAVERY}

As Price mentioned, they were made to see things through the Eurocentric perspective ${ }^{51}$, which must have rankled the more sensitive and intelligent ones among the enslaved Africans. The bitterness of the African Americans about this is revealed in the writing of a contemporary African American and AHIJ writer, Shalomim HaLevi. According to him, "We must die in the Spirit, mind, mentality, religions and ways of our Euro-gentile oppressors in which we have lived for 500 plus years." 52

I don't think that we would reasonably have any doubts that there were likely many of exceptionally high intelligence who were just unfortunate to have become captives and then slaves among the captives. Wynia said of Crowdy, "It is obvious that he had little sophisticated education. It is similarly obvious, however, that he was highly intelligent and a thinker of visionary proportions." 53

${ }^{51}$ Charles Price, Becoming Rasta (New York: University Press, 2009),117.

52 Shalomim HaLevi, Growing Intellectually, Spiritually and Prophetically In the Hebrew Israelite Culture and Faith. (Lincoln:iUniverse.com.Inc., 2001),15.

${ }^{53}$ Elly Wynia, The Church of God And Saints of Christ (New York: Garland Publishing, Inc., 1994), 20. 
From what he was able to accomplish we can only agree with Wynia. Writing in Ben Ammi's God, The Black Man And The Truth, his longtime friend Prince Gavriel HaGadol, said almost the same thing about Ben Ammi, "much of our youth was spent a block or so from the old Cabrini (now the notorious CabriniGreen) housing projects....in the forty-two years that I have known him l've yet to see him in any violent, physical confrontation, (which was a phenomenon in our neighborhood), even though he was a statewide wrestling champion. His strength was and is his unique insight and the precision of his tongue. He has an exceptional ability to discern and articulate. In this he has no equal-and I am not being partial." 54 So we can expect that the more sensitive ones must have read meanings into many things. For example they would have seen that the Eurocentric Christianity that was given to them reluctantly only served to reinforce the unjust socio-cultural system. All its motifs were 'white.' Even though Christian myths and history talk about Jesus as an Israelite, the picture of him that normative Christianity presents is that of an European ('white') man. Sensitive dark-skinned people have been offended by this. Ben Ammi took exception to this with the following words; "Consider some of the many beliefs, attitudes and teachings promulgated under this anti-God dominion that previous generations, not so long ago held dear:..... "Jesus" was a blue-eyed blondhaired European." ${ }^{55}$ And some of Christianity's teachings subtly endorse slavery.

\footnotetext{
${ }^{54}$ Ben Ammi Ben Israel, God, the Black Man and Truth (Washington: Communications Press,2004),1.

${ }^{55}$ Ben Ammi Ben Israel, God, the Black Man and Truth (Washington: Communications Press,2004),3.
} 
A good example of one such teaching is (Philemon 1:12-16) where Paul actually instructed a fleeing slave Onesimus to go back to slavery and to be faithful to his master Philemon who was advised to be kind to him. I think that it wouldn't have taken long for those that were more sensitive and intelligent like Crowdy and Ben Ammi to have began to think that that was one insult too many, and to begin to understand why the slave owners reluctantly agreed to give them and their ancestors the version of Christianity that they gave them. Parfitt discussed this in his Black Jews In Africa And The Americas. In his words: "There was usually a pious desire to convert Native Americans to Christianity but distinct reluctance to convert African slaves (unless it was to introduce them to the story of Noah and Ham in order to make them more submissive)." 56

Crowdy was to execrate Christianity when he received his vision to start the COGASOC. Wynia's narration of Crowdy's vision that impelled him to leave Christianity would be spoiled if it is summarized. He wrote, "He dreamt that he was in a large room and that tables were descending from above. The tables were covered with filthy vomit (similar to Isaiah $28: 8$ where it says "For all tables are full of vomit and filthiness, so that there is no place clean.") Each table was labeled with the name of a church (e.g. Methodist, Baptist, etc.). The biggest and dirtiest table was labeled Baptist, prompting Crowdy to resolve never to attend a Baptist Church again. At one point in the vision a small, clean white table came

\footnotetext{
56 Tudor Parfitt, Black Jews In Africa and the Americas (London: Harvard University Press, 2013), 70.
} 
down with the name 'Church of God and Saints of Christ' on it. Once it was firmly planted on solid ground it began to expand, displacing all the other tables. This was the sign to Crowdy that he was to establish a movement under this name which would be the 'true' church." ${ }^{57}$ As I understand it, this vision was a call on Crowdy to leave the oppressive culture which dehumanized the Blackman, and create another, the COGASOC, which will elevate the Blackman to his rightful place in society as the children of Abraham, Isaac, and Jacob. He did. He created COGASOC which was the first Black Jewish movement in the United States, and which was in the opinion of the COGASOC, the authentic expression of the faith of the Israelites-that the African Americans are their descendants. In the next section we will discuss COGASOC more intimately. We will try to see how its foundational myth of origin impacts its culture.

\section{ISRAELITES AND COGASOC}

Crowdy shook off the humiliating identity of slave and appropriated the identity Israelite which as have seen was inserted into the narratives of the AngloIsraelites, who commingled Israelite exceptionalism with racial supremacy to justify oppression of inferior peoples, among them the African Americans. From that point he proceeded to develop a unique religious movement with an identifiable culture which the movement recognizes, accepts, approves and preaches that it is the authentic Judaism. COGASOC is this movement. The

\footnotetext{
${ }^{57}$ Elly Wynia, The Church of God And Saints of Christ (New York: Garland Publishing, Inc., 1994), 21.
} 
basic tenet of the religious movement is already well known to us. It is that the African Americans are descendants of the biblical Israelites. There are other important tenets, taken from both the Old and the New Testaments. This is expected as Crowdy as a former Christian was well aware that a most important primary text of Judaism is the Hebrew Bible. Showing through clearly as well are the practices and beliefs of the Christianity that was the religion that was given to him when he was in bondage, and inserted too were practices and beliefs from another movement that he deeply associated with: the Freemasons. ${ }^{58}$

We would now look more closely at the organization that Crowdy started and some of the developments started by him. In this brief survey we would look at its history and culture, to see how the Israelite identity impacts on the movement.

Crowdy started the COGASOC in 1892, after receiving his vision. ${ }^{59}$ In his lifetime he started several congregations in several cities in the Midwestern and Eastern United States, and sent an emissary to organize branches in at least six African countries. The congregation later established locations in Cuba and the West Indies.

The COGASOC is the oldest African-American movement that its religion is in adherence to some of the tenets of Judaism. The COGASOC believes in

\footnotetext{
58 Jacob Dorman, The Rise of American Black Israelite Religions (New York: Oxford University Press,2013), 69.

${ }^{59}$ Elly Wynia, The Church of God And Saints of Christ (New York: Garland Publishing, Inc., 1994), ix.
} 
one God, preaches love of all humanity regardless of backgrounds, and upholds the Ten Commandments as the basis for ethical and moral living.

It teaches that the descendants of the biblical Israelites are peoples of African descent. But it also believes that anyone, be they of Israelite extraction or not can embrace Judaism and become a member of COGASOC. COGASOC does not see Jesus as God or the son of God, but rather as a strict Jewish prophet, in the same mold as Crowdy.

Some of the rituals drawn from the Old Testament include circumcision of newborn boys, use of the Hebrew calendar, observance of Saturday as the Sabbath, and celebration of Passover and other religious holy days specified by the Bible. The wearing of kippot is drawn from Jewish custom though it is not required in the Old Testament.

The New Testament rituals of COGASOC include baptism (immersion), the consecration of bread and water as Christ's body and blood, and foot washing.

From the foregoing we can see that while the COGASOC claims that its religion is Judaism that many of its beliefs and practices and practices are counter to the beliefs and practices of what we tend to look as normative Judaism. This is expected as COGASOC does not see what we view as normative Judaism as authentic. As well COGASOC argues that the adherents of normative Judaism are inauthentic Israelites.

To COGASOC, what it believes and practices some of which as we can see align with the faith of the Israelites in the Old Testament, is the authentic Judaism. 


\section{ISRAELITES AND AHIJ}

Ben Ammi who came much later and met conditions that were similar to those met by Crowdy reacted the same way, and made similar choices which today form central tenets of the AHIJ. The AHIJ moved further to consolidate its claims that the Black people were the authentic Israelites by making or constructing Israel into an African entity in its Divine Geography. In the article Israel as Africa, Africa as Israel: "Divine Geography" in the Personal Narratives and Community Identity of the Black Hebrew Israelites, Fran Markowitz of the Ben Gurion University wrote; "The Black Hebrew Israelite Community, centered in the dusty desert town of Dimona, Israel, challenges this conventional wisdom -(that Israel is in Asia/Middle East)-by providing proof positive that Israel belongs to Africa, and not to Asia." 60

AHIJ also intensified the efforts that its religious forebears like the COGASOC made to write the Black person back into religions that AHIJ felt that they had unjustly excluded persons of African ancestry from their sacred discourses.

The conscious shift of the AHIJ towards Africa is understandable however because AHIJ was started by a man that experienced the great revivalism of the African Americans by Marcus Garvey. A brief narration about Marcus Garvey and

\footnotetext{
${ }^{60}$ Fran Markowitz, Israel as Africa, Africa as Israel: "Divine Geography" in the Personal Narratives and Community ldentity of the Black Hebrew Israelites (Washington: The George Washington University Institute for Ethnographic Research, 1996).
} 
his work will be helpful because it will help us to understand a very powerful influence on the AHIJ.

Marcus Mosiah Garvey (1887 - 1940), was the Jamaican-born populist who was equated to Theodore Herzl. As a politician, publisher, journalist, and orator, using his Pan-African movement Garvey woke up the Negroes, as the Blacks in the United States were called then. His fire and zeal also woke up those in his native Jamaica, other Caribbean nations, and even the Africans in Africa. He preached with religious zeal that the Blacks were better than circumstances had made them to be. He also preached that before slavery that Blacks had been the light of the world, possessing empires and kingdoms, which the surviving Ethiopian empire of Emperor Haile Selassie was proof of. He not only preached about the greatness of the Blacks in the past, but he also took practical steps to restore the Blacks to greatness. He founded the Universal Negro Improvement Association and African Communities League (UNIA-ACL). He also established the Black Star Line, a shipping and passenger fleet as empowerment tools with which he promoted the return of the Africans who had been displaced by the slave trade to Africa. ${ }^{61}$ Ben Ammi tried to implement this aspect of Garvey's program by taking his fledgling movement which would in time transform to AHIJ to Liberia.

Prior to the 20th century, other black leaders had tried to wake up and galvanize the Blacks in the Americas and all over the world into mass action: to reclaim

${ }^{61}$ http://www.history.com/topics/black-history/marcus-garvey-03/17/17 
leadership of the African continent from European colonialists, and to get those that were born in the Diaspora to lead this effort. However, it was Garvey that succeeded in formulating a Pan-African philosophy that inspired Blacks everywhere to focus on Africa. Garvey's philosophy was known as Garveyism. Garveyism had a religious undertone. Promoted by the UNIA as a movement of African Redemption, Garveyism would eventually inspire many which included Ben Ammi. Garveyism essentially saw Africa as one bloc. This again is reflected in Ben Ammi's relocation of his flock to Liberia, which he saw, as he also saw Israel, as just a part of Africa.

\section{AHIJ AND CULTURE}

We will now begin to look more intimately at the culture of AHIJ. Ben Ammi, like Garvey, preached about the former greatness of the Blacks. In his book God the Black Man and Truth, he wrote, "Africa was a powerful land whose people had tremendous faith in God prior to 1555(when the first slaves from Africa reached America) for it was Black African brothers—Moses, Jesus and Mohammed—who set the tone for the basis of the world's three major religions: Judaism, Christianity and Islam. The truth concerning this matter cannot be found in the history and religious books of Europe or America."62

As we have mentioned or hinted, the AHIJ is quite more Africa-centered in its ideology than the COGASOC. As we have also explained, this is likely

\footnotetext{
${ }^{62}$ Ben Ammi Ben Israel, The Revival of The Holy Spirit (Washington: Communications Press, 2004), 24
} 
because it developed after Marcus Garvey had made Africa central in the consciousness of the African Americans and Caribbeans. The AHIJ redefined Geography by redefining Israel which is crucial to the identity of AHIJ as an African country. The movement developed some ideas found in COGASOC further. It has been said that Crowdy as a former cook who was familiar with the Old Testament and saw it as the more important of the two testaments had some positive thoughts about the food laws in the Torah. The AHIJ subsist on a vegan diet and they shun alcoholic drinks-drinking only their home-made fermented wine. This is a part of their religious life.

The AHIJ unlike the COGASOC teach and practice polygamy which they believe that the Bible endorses, and they cite as examples of polygamists highly revered Israelites like Kings David and Solomon.

Like the COGASOC they believe that their own form of Judaism is the authentic one, and that both Rabbinic Judaism and Christianity are not authentic. They believe that Yah which is their preferred Name for the Supreme Being, gave the Old Testament to the Israelites that are their forebears. They accept the New Testament too as a record of the life and times of Yeshua (Jesus), whom they see as a prophet, and one of the messiahs sent by Yah to keep the people of Israel in the ways of righteousness. However they place a lower value on the New Testament. Presently Ben Ammi who died in 2014 is regarded as a messiah by the AHIJ.

Ben Ammi taught that Africans are the victims of machinations and plots to control them with religion. He taught that the plot succeeded because Blacks 
disobeyed the laws and commandments of God. He explained the Black experience during the trans Atlantic slave trade as the consequence of violating God's laws, statutes and commandments, and that this led to the activation of the curses in Deuteronomy 28:68, which speaks of a second captivity in a second Egypt which the Israelites would be carried to in ships. He maintained that the Euro-gentile conspiracy which turned Israel into an Asian or Middle Eastern entity concealed the true color of the ancient Hebrews and perpetuated the falsehood that Jesus was white to maintain the fiction that the ideal was white. To free AHIJ members from seeing things from the perspectives of the Eurogentiles Ben Ammi called for all things to be reexamined and redefined. ${ }^{63} \mathrm{He}$ argued that Euro-gentiles have innocuously welded power by having defining things. I think that he remembered what the society that the Euro-gentiles built and controlled did: it enslaved free people, de-ethnicized or deracialized them, and bequeathed the identity 'slave' and ex-slave' to people who were born free in Africa. And it went further to construct a racial category out of this slave status, for the Black people, thus attempting to link the dark-skin to slavery. Ben Ammi having seen what his perceived foes could accomplish spared no effort in combating them. He taught that this same power that could be used to subjugate could be used to achieve salvation.

Ben Ammi essentially saw the need for a new World Order; a new world that will replace the intrinsically corrupt one that exists presently. And at a point it

\footnotetext{
${ }^{63}$ Ben Ammi Ben Israel, God-The Black Man Truth And Power (Washington: Communicators Press, 1982), 47.
} 
becomes clear that his vision which is the vision of AHIJ is beyond just the improvement of the lot of the Blacks, but that he actually dreamed about making the whole world a better place by reforming mankind. He taught that the new world would be the Kingdom of God. His vision was that AHIJ would serve as a beacon, a light to the gentiles. We can see this from the angle that at a point the AHIJ though still maintaining that the biblical Israelites were black people began to agree that even gentiles that observe the commandments of Yah can attain Hebrew status.

AHIJ's belief is that there is no distinction between the secular and the sacred. To AHIJ the whole and everyday activity of the righteous person should reflect worship.

AHIJ believes that the value system of a society is seen through its culture. Accordingly AHIJ shows its respect for nature according to it, through clothing, music, food and even language which according to AHIJ reflect the glory and the higher standards of Yah. As in food, their clothing is made from natural fibers. AHIJ food is called 'soul food', and AHIJ members are called 'saints.'

As the group has taught that Israeli Jews are impostors, and did maintain mutually hostile relations with the Israeli state for a long time, it had taken some steps that has led to charges of anti-Semitism being leveled against both Ben Ammi and AHIJ. AHIJ had in turn accused the Israelis of racism and usurpation of African territory. But on the positive side relations have improved between the group and the Israeli state in recent years. Both sides are co-operating. AHIJ 
members have represented Israel twice in the Eurovision song contest and a few have volunteered for service in the Israel Defense Force (IDF).

In August 2008, Israel's then president, Shimon Peres visited the Village of Peace at Dimona, and said friendly things about the Hebrew Israelites. Writing in the Forward, Andrew Esensten observed that Shimon Peres said to the AHIJ: "Your community is beloved in Israel," ........ "You give the country happiness and song and hope for a better world." ..... "Our hands are in yours; your destiny must be our destiny." 64

As we have seen, both COGASOC and AHIJ have elaborate cultures, and programs which they have managed to implement with outstanding results. Very clear too is that while they take their claims of Israelite ancestry very seriously, they also place maximum value on their Blackness. We will now look at why this is the case. AHIJ being more Afro-centric will make a better subject for this study so we will concentrate more on it, while not neglecting COGASOC.

\section{BLACK AND JEWISH}

The image, position, and 'race' of Israel, and Judaism in the United States at the time that both movements were born has to be considered very carefully to get at the reasons that are likely to be the ones behind the vigorous maintenance of the tradition or position that the two movements are Jewish, and Black.

\footnotetext{
${ }^{64}$ Andrew Esensten, Forward (http://forward.com/news/104067/once-reviled-black-hebrews-nowfeted/2009)
} 
In the United States, in the antebellum period, race was very important. Many things were seen through the racial prism. Some things were 'white', and some things were 'black.' Judaism was 'white', and the slaves were black, as was slavery itself. COGASOC and AHIJ in maintaining that African Americans are the descendants of the Israelites, and their religion Judaism had to see, and agree that Black people belonged to ideas, religions, and entities that were solidly believed to be in the 'white category.' In the understanding of the society black was black, and white was white. We can see the enactment of the law of the 'one drop rule' as an attempt to keep the Blacks in their place, which in the understanding of the society was the place of the slave race. The founders of COGASOC and AHIJ were members of the society that produced a culture that had the idea or saw the world in such racist terms. They too likely believed that there could not be white Jews and black Jews, yet they claimed and asserted that they were Israelites. This could only mean one thing to them: the Jews of non African backgrounds were not authentic. They were impostors. If they were not impostors they would have been Blacks! The very nature of Judaism as a racialized religion in the West at the period that the Blacks became Israelites is one factor that cannot be over-emphasized. The two movements also counterracialized Judaism. It became in their world view a religion of Africans stolen by persons of non African backgrounds.

At this stage we will look at one of the theories that is pertinent to understanding the two movements, which are essentially hybrid movements. They both take their Blackness as seriously as they take their Israelitishness. We 
will caption the next sub-section deracialization and hybridization, because from what we are seeing deracialization which was one of the after-effects of their enslavement helped to hybridize their culture.

\section{DERACIALIZATION AND HYBRIDIZATION}

One of the theories we are looking at in tracing the ethno-history of these groups is the theory that deals with how deracialization or deracination leads to, or could lead to hybridization. The subjects in question are both 'Blacks' or African Americans and Israelites in culture at the same time, due to the deracination that they suffered. What we are looking at in essence is a hybrid culture: A culture that is both Black and Israelite. From what we have seen so far, in the main one of the major planks on which their Jewishness rests is that their Blackness is one of the proofs of their descent from the ancient Israelites. And from what we saw in the program of AHIJ, the movement is as much African/Black as it is Israelite. Its culture is both Black and Israelite.

Homi Bhabha in his work, The Location of Culture explored the phenomenon of hybrid cultures intensively. He views hybridity as the outcome of tensions that arise due to the problems that accompany colonialism. According to Bhabba, colonialism itself comes with cultural forms, including new identities, for the colonized, which adds to what the colonized already possesses-leading inevitably to hybridity. He argued that this leads to the production of cultures that when compared to the 'originals' they show that they are what he called mimicries. 
Different peoples have throughout history been subjugated, mixed, deracinated, reracinated, and had ended up hybridized peoples. Also, as a result of the mixtures which forcefully changed the identities of groups, and foisted on same groups other identities, we have had hybrid cultures, because some of the results and outcomes of resisting the 'change' are new cultures which are hybrid as sometimes the involved try to retain what was, or what was thought to have been, and what came up as a result of resistance to subjugation or colonialism.

The COGASOC and AHIJ have generally not shifted from the basic myths handed down by the founders of the two movements. As we have seen COGASOC maintains that the Black man is the authentic descendant of the Israelites, but while AHIJ has the same view it has gone further to make Africa an essential part of its history and theology, which interestingly it claims that they are old truths suppressed by Euro-gentile oppressors.

\section{CHAPTER FOUR}

\section{CONCLUSION}

We set out to explore the ethno-history of two very interesting Black Israelite movements: Church of God and Saints of Christ, and African Hebrew Israelites of Jerusalem, that are distinguished by their claims that African Americans are the authentic descendants of the Biblical Israelites. 
In the first chapter which is the introductory section, we introduced the two movements, briefly talked about their founders, the departed African Americans; Prophet William Saunders Crowdy, and Ben Ammi Ben Israel. We also briefly discussed the just mentioned basic claims of both movements, the periods that they started, the conditions that were prevalent during the periods of their initiation, and the possibility that the conditions influenced or provoked the creation of the two movements.

In this introductory section we noticed that a prominent question was already very evident: why did African Americans appropriate an Israelite ancestry? We discussed the methodology and theoretical models that we would engage to enable us to get a better understanding of the subject, and from there we mentioned some of the literature that we would analyze in the effort to both study the subjects, and present our findings in very clear, lucid and understandable terms. We also mentioned the kind of sources that we would look into, to find good information about the two groups. We closed chapter one by enumerating our work plan. This is about which subject we would look at, and when, so that our work will flow smoothly.

In chapter two we discussed Israel from numerous angles because of the importance of Israel both to the movements and the study. The two movements claim Israelite ancestry for African Americans, and claim that their sins against God made them lose the Land of Israel, and interestingly view Jews who are not black as impostors. After discussing Israel as the location that is very important 
to one of the movements, we engaged Israel as a people. This led us to a discussion about how the Israelite people became a distinct people when they began to adhere to a particular culture: which is akin to what we saw in our study of African Americans whom the culture of the United States in the antebellum period helped to forge into the Black Israelite people. Here we encountered the first methodology we engaged and wrestled with, which holds that culture, not biology forges people.

Proceeding, we discussed differences between Black Israelites which is the category that COGASOC and AHIJ fell into, and Blacks that adhere to Rabbinic Judaism, because while both groups differ in many material respects they are often conflated together because of a reason that is very pertinent to this study: the racialization of Judaism. In the public imagination, Judaism is a white religion, and all non whites that adhere to it are not viewed as traditional Jews; and to put it another way, they are not viewed as authentic. Interestingly this perception of Judaism as a race-bound religion was to be one of the reasons that would impel the African Americans to adopt and appropriate an Israelite identity so successfully.

In chapter two we explored the culture of the slave owning society that forged COGASOC and AHIJ, because what we had seen from the research that the two movements were responses to the extremely difficult conditions that the slave owning society imposed on Blacks. As we saw it, if Crowdy had not been a slave he might not have started COGASOC. We also thought that if Black 
conditions had not remained terrible and very difficult after slavery had been abolished that Ben Ammi might not have formed AHIJ. It was our observation that both movements were products of slave conditions in the United States. Accordingly, a study of their ethno-history has to seriously investigate Black and slave conditions during slavery and after it. Also, the culture in the territory must be closely examined because it is the culture that determined how the slave was viewed, perceived and treated. Coming from this angle we were not disappointed. The horrible treatment of the slaves which included deracialization, and foisting of a slave category permanently on their color was the main reason that forced the unarmed slaves and ex slaves to rise up and take action with religion. We followed and studied the United States in the antebellum period very carefully, giving particular attention to its culture. Evil world it was but still ideas that could be exploited by the intelligent floated around in it. Some ideas circulated that the British were supreme because they were Israelites, thereby feeding into the society the idea that being descendants of the Israelites was ennobling. From the same source too ideas that implied that non Israelites were inferior floated around. Meanwhile we saw the slaves encountering the Israelites in many ways. They encountered them in the Old Testament as the Hebrew slaves that Pharaoh treated as they (the slaves) were treated in the antebellum world. We surmised that it'd have been hard for the already deracialized slaves not to have identified with the enslaved Israelites, and seen them as kindred souls at least. Meanwhile, the culture kept on producing information about Jews in the land from which they (the slaves) were taken captive. Freed slave 
Equiano's book found its way across the Atlantic. Runaway slave Pennington's book circulated in the United States, and both of them discussed information that created the possibilities that there were Jews in the land of origin of the oppressed slaves. More of such information was released. In addition in this chapter we discussed that Blacks may have actually met Black Jews too, and this could only have helped to stir in them feelings that they were Jews. In this chapter we also discussed how the relentless culture of abuse of Blacks continued to be alive even after the slaves had been granted their freedom by law. Crowdy, who was a slave, responded to the mistreatment by declaring that African Americans were descendants of the Israelites, and creating a religious movement which would attempt to solve the unique problem of Blacks. We discussed how this worked. With the adoption of a more dignified identity, Blacks discarded the horrible one that was imposed on them. This new religion which Crowdy created would free Blacks from the oppressive culture that was not in any way helpful to them. It granted them freedom and dignity because the culture of the new religion was designed to edify Blacks. From what we saw, what led to what Crowdy did was the process of enslaving Blacks, dehumanizing and deracializing them, and creating a racial category out of their pitiable condition. In light of this, we discussed the birth of both COGASOC and AHIJ as responses to the brutal conditions that the Blacks had to contend with.

Before we ended Chapter two, we compared two other movements: the Moorish Movement and the Rastafari Movement that were also started by African Americans and Caribbeans that had experiences that were similar to 
what the founders of COGASOC and AHIJ passed through. Their responses were equally similar. Once again we saw that it was culture and not Biology that forges people, and that as the Black Israelites were forged by the culture of the antebellum world, so were the Moorish Muslims and the Rastafari.

In Chapter three we began to analyze more critically the effects of the culture of the antebellum world on the Blacks, and how it impelled them to respond by appropriating an Israelite identity, which they connected to their Black color and identity. Furthermore, they developed a religious culture that was based on the appropriated myth, that was in sharp contrast to the culture of the antebellum world. From here we looked at the effects and pressures of colonialism and slave trade on African Americans who ended up producing a hybrid culture as a response to the cultural norms that the oppressive culture of the antebellum world applied and imposed on them.

While engaging in this study we found that the COGASOC and AHIJ are essentially African American responses to the mistreatment that they suffered at the hands of the slave masters. In addition, they appropriated an Israelite identity because the identity was available as one of the identities in the antebellum world that fitted their circumstances for various reasons. The oppressive culture prepared African Americans to appropriate this identity by deracializing them. The culture further prepared the slaves by making available to them the Bible, in which they read about the Hebrews who were like themselves enslaved, but were eventually freed; events that from what we saw made the slaves to start to 
develop a kindred spirit with the Israelites. Also, the culture of slavery that produced individuals like Equiano and Pennington who brought information about 'Jews' from the homelands of the African Americans helped to lead the African Americans to the belief that they belonged to the Israelite race, and not the 'slave race' as the culture of the antebellum world tried to tell them. Because the culture of this world did not prepare the African Americans to accept that white could be Jewish and black Jewish, when they declared themselves Jewish they in conformity with the dictates of the culture and society ruled that the whites who were Jewish were impostors. And henceforth they began to developthe COGASOC and AHIJ which are to them the authentic versions of Judaism, and which to them was originally an African religion.

We saw that though both COGASOC and AHIJ, (and AHIJ more-so lay claim to be movements in which the blacks (Africans) are central), the Black Israelite movement in general and COGASOC and AHIJ in particular may not have been born if the founding fathers had not experienced slavery in the Americas. We arrived at this after finding that both movements were spawned as responses to the oppressive conditions that African Americans had to bear during slavery and even after slavery had ended. So we cannot call both movements African religions. At best, we can call them religions started by persons of African descent in the New World. Looking at this, Jacob Dorman wrote, "First rather than narratives of the Israelites being transmitted with enslaved Africans, who were themselves descendants of the ancient Hebrews, this book (his book) demonstrates that Crowdy's church introduced Black 
Israelite theologies to Africa at the start of the twentieth century. His Black Israelite practice developed from the particular history of African American suffering ...."65

As we have mentioned, essentially both movements were 'resistance movements', and they were primed to restore the real independence and dignity of the black man, by reclaiming what the founders felt was the real lost identity of the African American, and going back to the true religion. In doing so, COGASOC and AHIJ helped the African Americans that followed the movements to find meaning in the wretched existence that they faced after the end of slavery. The central and foundational belief of COGASOC and AHIJ which is essentially that African Americans are the descendants of the biblical Israelites has much power. It placed African Americans at the summit of the human race. With this identity, the members of COGASOC and AHIJ faced the society with confidence. From the ex slaves they became the Israelites, blood relatives of Abraham, Isaac, Jacob, Moses and Jesus who had like their forebears the power and authority to tell the world the truth about everything; from the divine, to the mundane and secular. With COGASOC and AHIJ, we encountered the Black man that was ready to face his erstwhile oppressors as an equal or superior.

\footnotetext{
${ }^{65}$ Jacob Dorman, The Rise of American Black Israelite Religions (New York: Oxford University Press, 2013), 8.
} 


\section{NOTES}

1. I used Rabbinic Jewish community in this study as the best term to be used to describe what some have called the 'normative Jewish community'-an inappropriate term if I may say. The group that I refer to are Jews of European, and Middle Eastern extractions.

\section{BIBLIOGRAPHY}

Azoulay, Katya Gibel. Black, Jewish, And Interracial. Durham: Duke University Press, 1997.

Barnett, Michael. Rastafari. New York: Syracuse University Press, 2012.

Ben Israel, Ben Ammi. God, the Black Man and Truth. Washington: Communications Press, 2004.

Ben Israel, Ben Ammi. God And The Law of Relativity. Washington: Communications Press, 1991.

Ben Israel, Ben Ammi. Everlasting Life. Washington: Communications Press, 1994.

Ben Israel, Ben Ammi. Yeshua Hebrew Messiah Or Jesus the Christian Christ. Washington: Communications Press, 1996.

Berger, Graenum. Black Jews In America. N.Y: C.S.R.FJ.P,1978.

Biale, David. Cultures of the Jews. New York: Shocken Books, 2002.

Bhabha, Homi. The Location of Culture. New York: Routledge, 1994.

Brettschneider, Marla. The Jewish Phenomenon In Sub-Saharan Africa .New York: The Edwin Mellen Press, 2015.

Brotz, Howard M. The Black Jews of Harlem. New York: Schocken Books, 1970.

Chevannes, Barry. Rastafari. New York: Syracuse University Press, 1994.

Chireau, Yvonne and Deutsch, Nathaniel. Black Zion. New York: University Press, 2000. 
Dorman, Jacob Chosen People: The Rise of American Black Israelite Religions. New York: Oxford University Press, 2013.

Equiano, Olaudah. The Interesting Narrative of the Life of Olaudah Equiano. Boston: Bedford/St Martin's, 2007.

Geertz, Clifford. The Interpretation of Cultures. New York: Basic Books, Inc, 1973.

Gerber, Israel J. The Heritage Seekers.New York: Jonathan David Publishers, 1977.

Goldenberg, David M. The Curse of Ham. Princeton: Princeton University Press, 2003.

Goldschmidt, Henry. Race And Religion. New Brunswick: Rutgers University Press, 2006.

HaLevi, Shalomim. Growing Intellectually, Spiritually and Prophetically In the Hebrew Israelite Culture and Faith. Lincoln:iUniverse.com, Inc.2001.

Hare, A. Paul. The Hebrew Israelite Community. Oxford: University Press of America, 1998.

Jackson, John. Thin Description. Cambridge: Harvard University Press, 2013 Katz, Shlomo. Negro and Jew. New York: Macmillan, 1966.

Kaye, Melanie/Kantrowitz. The Colors of Jews. Bloomington: India University Press, 2007.

Kidd, Colin. The Forging of Races. Cambridge: Cambridge University Press, 2006.

Korn, Bertram Wallace. Jews And Negro Slavery In The Old South 1789-1865:

Pennsylvania: Reform Congregation Keneseth Israel Elkins Park, 1961.

Landing, James E. Black Judaism. Durham: Carolina Academic Press, 2002.

Lis, Daniel. Jewish Identity Among The Igbo of Nigeria. Trenton: Africa World Press), 2015.

Lobagola, Bata Kindai Amgoza Ibn. An African Savage’s Own Story. N.Y: Alfred A. Knopf, 1930. 
Malcion, Jose V. The African Origins of Modern Judaism. Trenton: Africa World Press Inc, 1996.

McCarthy, Karen. Mama Lola-A Vodou Priestess in Brooklyn. Berkeley: University of California Press, 1991.

Parfitt, Tudor. Black Jews In Africa and the Americas. London: Harvard University Press, 2013.

Parfitt, Tudor, Fisher Netanel. Becoming Jewish-New Jews And Emerging Jewish

Parfitt, Tudor, Egorova, Yulia. Genetics, Mass Media and Identity: A Case Study of the Genetic Research on the Lemba. London: Routledge, 2014.

Communities In A Globalized World. Newcastle upon Tyne: Cambridge Scholars Publishing, 2016.

Parfitt, Tudor. Journey To The Vanished City. London: Vintage Departures, 1992.

Parfitt, Tudor. In The Shadow of Moses. Newcastle upon Tyne: Cambridge Scholars Publishing, 2016.

Parfitt, Tudor. The Lost Ark of the Covenant. London: Harpers Collins, 2008. Rahier, Jean Muteba. Representations of Blackness and the Performance of Identities. Westport: Bergin \& Garvey, 1999.

Shadrock, By. The Forgotten Israelites. Toronto: Fifth Ribb Publishing, 1991.

Segev, Tom. One Palestine Complete. New York: Henry Holt And Company,2001.

Walker, Rebecca. Black White And Jewish. New York: Riverhead, 2001.

Windsor, Rudolf. From Babylon To Timbuktu. Chicago: Lushena Books, 1969.

Windsor, Rudolf. The Valley of The Dry Bones. Atlanta: Windsor's Golden Series, 1986.

Wynia, Elly M. The Church of God and Saints of Christ. New York: Garland Publishing, Inc, 1994. 